\title{
CARL SCHMITT X HANS KELSEN: DEFENSOR OU SENHOR DA CONSTITUIÇÃO?
}

\author{
CARL SCHMITT X HANS KELSEN: DEFENDER OR SEIGNIOR OF THE \\ CONSTITUTION?
}

Roberto Bueno Pinto*

\begin{abstract}
RESUMO: a crise política das democracias contemporâneas encontra suas razões em antigos argumentos elaborados pelos detratores da teoria e prática democrático-parlamentar. O debate entre Schmitt e Kelsen sobre o guardião da Constituição e a (i)limitação que deveria marcar o exercício de seu poder contém uma destas razões jurídico-políticas que transcende o seu tempo. Sugerimos que ela se encontra todavia pulsante e preenche uma das tantas ranhuras da crise das democracias contemporâneas; a saber, o inconcluso debate sobre a supremacia do direito sobre a política ou da política sobre o direito ou, ainda, sobre a preeminência da técnica sobre o mundo da vida (Lebenswelt) ou, ângulo inverso, do mundo da vida sobre qualquer tipo de regulamentação voltada ao asseguramento das liberdades. Partindo desta premissa, este texto procura reconhecer quem - à parte a autopercepção de ambos os autores sobre suas teorias - realmente sustenta teoria composta por um defensor e quem por um senhor da Constituição.
\end{abstract}

PALAVRAS-CHAVE: Carl Schmitt. Hans Kelsen. Controle de constitucionalidade. República de Weimar. Ditadura.

ABSTRACT: The political crises of the contemporary democracies find their explanation in the past arguments composed by detractors of the parliamentarian democratic theory and practice. The debate between Schmitt and Kelsen on the protector of the Constitution and the (il)limitation, which must characterize the exercise of its power, contains one of the juridical and political reasons that exceeds its own time. We suggest that reason still beats and fulfills one of the many grooves of the contemporary democracy's crisis, i.e., the unfinished debate on the supremacy of law over politics or politics over law, or still, the supremacy of the technique over the world of life (Lebenswelt) or, instead, the world of life over any type of regulation turned to assure the liberties. Starting from that premise this article looks to recognize - aside the self-perception of each author about his theories who really support a theory composed by a defender, and who by a seignior of the Constitution.

KEYWORDS: Carl Schmitt. Hans Kelsen. Judicial Review. Weimar Republic. Dictatorship.

\footnotetext{
* Professor Adjunto III da Faculdade de Direito da Universidade Federal de Uberlândia no Curso de Graduação (Teoria do Estado e Democracia; Filosofia do Direito, Filosofia Política). Pós-Doutor em Filosofia do Direito e do Estado (UNIVEM / 2015). Doutor em Filosofia do Direito pela Universidade Federal do Paraná (UFPR / 2011). Mestre em Filosofia Política pela Universidade Federal do Ceará (UFCE / 2012). Mestre em Filosofia do Direito e Teoria do Estado pela Fundação de Ensino Eurípides Soares da Rocha (2006). Especialista em Ciência Política e Direito Constitucional pelo Centro de Estudos Constitucionais de Madrid (1994). Graduado em Direito pela Universidade Federal de Pelotas (1992).E-mail: rbueno_@hotmail.com
} 


\section{INTRODUÇÃO}

Incialmente importa destacar a motivação do recorte do objeto deste texto. Sugerimos que é importante que a ditadura e os períodos de exceção sejam devidamente considerados, assim como as competências das autoridades por eles responsáveis. O fato é que experimentamos tempos em que as crises políticas e econômicas sugerem o governo político segundo regras excepcionais, fugidias à tramitação política parlamentar; de resto, bastante vituperada pelas forças conservadoras e reacionárias. Portanto, assim como em seu momento a democracia, as forças nela operantes devidamente rearranjadas, e compreendidas para mais além da tradicional divisão esquerda-direita, postam-se em face das fileiras reacionário-conservadoras de viés fascista de modo travestido, como se de democratas de boa cepa, e não de mera oportunidade se tratasse, apresentando-se não raro sob o argumento da indispensável guarda do mundo das finanças e do establishment econômico, ainda que a expensas da vida dos homens ordinários.

No que concerne especificamente a Schmitt, não está em causa opor as posições, por exemplo, de Arthur Kaufmann e Helmut Quaritsch a respeito do completo desvalor ou do valor das escolhas de Schmitt, senão tomar em perspectiva o valor, isto sim, de seu trabalho, que, é sabido, não manteve em qualquer momento simpatia pela democracia parlamentar e pelas suas instituições filosófico-políticas liberais. O que está em causa neste texto é, pontualmente, o debate constitucional mantido entre Carl Schmitt e Hans Kelsen sobre o guardião da Constituição, polêmica que se extende por diversas conexões que, então, tornam de extrema atualidade um debate que poderia sê-lo apenas do ponto de vista historiográfico. ${ }^{1}$

A polêmica entre Carl Schmitt e Hans Kelsen teve lugar pelas muito diversas visões de mundo, de filosofia e de política, com uma inflexão positiva sobre a teoria jurídica de cada um deles que logo ficaria bastante clara em duas grandes obras, a saber, O guardião da Constituição (Der Hüter der Verfassung), publicada por Schmitt em 1931 a partir de um primeiro texto publicado em 1929 na Archiv des öffentlichen Rechts (AÖR), mas que, do ponto de vista conceitual, encontra os seus claros antecedentes em sua Verfassungslehre (1928). ${ }^{2}$ Logo na sequência da publicação de seu livro, Schmitt obteve a reposta de Kelsen em seu breve e denso texto intitulado Quem deve ser o guardião da Constituição? (Wer Soll Hüter der Verfassung sein?), publicado por Kelsen em 1931 na revista berlinense Die Justiz. Em torno dessas duas obras é que este texto oscilará, não sem considerar obras paralelas relevantes de ambos os autores.

\footnotetext{
${ }^{1}$ Para uma perspectiva panorâmica sobre a obra de Schmitt, há obra coletiva de recente publicação (ver BUENO, 2015).

${ }^{2}$ Há interpretação de Franco de Sá sobre a origem em texto de juventude, o seu Der Werte des Staates, de 1914 (cf. FRANCO DE SÁ, 2012, p. 90).
} 
O que está em questão e representa o eixo fundamental neste debate Schmitt-Kelsen sobre quem é e quem deve ser o guardião da Constituição é, nesta dimensão, então, o questionamento se deveria sê-lo a justiça constitucional (Kelsen) ou uma figura popularmente ungida (plebiscito), nominadamente, um Reichspräsident ou Führer (Schmitt). Em suma, estavam em debate os limites e as fronteiras do direito enquanto técnica e, por outro lado, a compreensão do poder e da política como antessala do direito posto. Schmitt manteve a perspectiva de que o perfil do guardião da Constituição melhor se encontrava à parte do mundo legal, residindo em uma zona limítrofe, cinzenta e sinuosa, localizada entre a política (fenômeno pré-jurídico) e o direito propriamente dito (direito posto). Via inversa, encontrava em Kelsen a crítica favorável à instauração de um Tribunal exclusivo para cuidar da guarda constitucional (KELSEN, 1995, p. 8), visto que, na visão de Kelsen, transformar o Presidente do Reich no único defensor da Constituição implicaria uma violação às normas da Constituição de Weimar (KELSEN, 1995, p. 68).

O que esteve em causa neste debate foi a precedência, ou não, da política (poder) sobre o direito (técnica) e, não menos, a determinação da preeminência de um deles sobre o outro. No caso de Schmitt, teve lugar a afirmação nem sempre expressa da política sobre o direito (governo dos homens) e, no caso de Kelsen, do direito sobre a política (governo das leis). Este foi argumento suficiente para Schmitt atacar Kelsen quando este pretendeu que a soberania pudesse caber ao direito (Estado), e não a política (soberania) ${ }^{3}$ tal como propunha Schmitt, e neste sentido sentia-se à vontade para afirmar que “[...] da $\beta$ nicht der Staat, sondern das Recht souverän ist” (SCHMITT, 2009b, p. 29). ${ }^{4}$ A determinação pontual de quem decide é o que realmente importa para a realidade da vida jurídica (SCHMITT, 2009b, p. 40) e isto, certamente, não pode ser determinado por uma norma, como sugere Kelsen em sua teoria escalonada do ordenamento jurídico, senão, diria Schmitt, que à base de tudo estaria uma vontade humana e, em suma, uma decisão.

No caso específico de Kelsen, a sua compreensão da importância da atribuição da competência da guarda constitucional a um organismo jurídico passava por sua leitura do valor da neutralidade liberal, criticada por Schmitt por seu viés abstencionista que havia sido adotado como

\footnotetext{
${ }^{3}$ Em sua leitura do Estado puro de Wolzendorff, Schmitt chamava a atenção para que, nele, o Estado deveria operar como garante (Hüter) do direito, e não como o seu senhorio (Gebiete), mas que isto tampouco deveria sugerir que o Estado fosse tão somente um "blinder Diener" (servidor cego), senão que lhe caberia uma posição ativa, ou seja, responsável, e que, enquanto tal, aquele que teria a última palavra ou, em seus termos, que “[...] verantwortlicher und letztentscheidender Garant” (SCHMITT, 2009b, p. 33).

${ }^{4}$ Uma livre tradução sugerida para o trecho é: “[...] que o soberano é o direito, e não o Estado”.
} 
premissa para as Constituições modernas (SCHMITT, 1996, p. 78). ${ }^{5}$ Kelsen apostou na imparcialidade que poderia ser inspirada por meio do cultivo de uma perspectiva técnico-jurídica, e não política, que inspiraria o Tribunal, no qual a ciência do direito poderia triunfar segundo a medida de sua teoria pura do direito em que o corte epistemológico haveria de ter sido realizado à medida para que tal estrutura imparcial fosse realizada. Por sua vez, para Schmitt, o órgão protetor da Constituição não poderia ser neutro assim como pretendia o liberalismo. Para Schmitt, esta visão era merecedora de crítica, pois, argumentava, esta perspectiva era precisamente o inverso de sua concepção de democracia, ou seja, que “[...] die Einsetzung eines derartigen Hüters der Verfassung der politischen Konsequenz des demokratischen Prinzips direkt entgegengesetzt” (SCHMITT, 1996, p. 155), ${ }^{6}$ e o motivo disto era o distanciamento da ação do órgão protetor de sua vinculação com a população, dado que os tribunais não passariam de órgãos aristocráticos.

A esta crítica de Schmitt, Kelsen responderia pontual e precisamente que o controle de constitucionalidade realizado por um Tribunal não seria menos democrático do que aquele realizado por um Chefe de Estado, ${ }^{7}$ pois a qualidade de ser democrático de um Tribunal estaria apenas na dependência de seu modo de designação, a saber, de ser eleito popularmente, e de organizar profissionalmente a sua estrutura (KELSEN, 1995, p. 72-73).

Mas, se as respostas oferecidas por Schmitt e Kelsen a muitos dos objetos de suas análises são efetivamente divergentes, isto sim, há, ao menos, um movimento em comum, a saber, que em face da Constituição deveria ser concebido e proposto um guardião dela. Para Kelsen, por tal se deveria entender aquele órgão que tivesse por função a defesa da Constituição contra violações (KELSEN, 1995, p. 3), ideia que, certamente, seria compartilhada por Schmitt, que indicava que tal demanda era típica de tempos de crise, ou seja, que "Der Ruf nach einem Hüter und Wahrer der Verfassung ist meistens ein Zeichen kritischer Verfassungszustände” (SCHMITT, 1996, p. 1), ${ }^{8}$ e esta era, com clareza, a situação de Weimar, como também, e com radical agudeza, a do regime nacional-socialista, ditadura ácida cuja crueldade não foi suficiente para levar Schmitt a fazê-la

\footnotetext{
5 Segundo Schmitt, "Dieser im liberalen, nichtinterventionistischen Sinne gegenüber der Gesellschaft und der Wirtschaft grundsätzlich neutrale Staat bleibt auch dann die Voraussetzung der Verfassungen [...]”. A livre tradução sugerida para o trecho é: "No sentido liberal e abstencionista, este Estado fundamentalmente neutro relativamente à Sociedade e à Economia também veio a ser a premissa das Constituições”.

${ }^{6}$ Uma livre tradução sugerida para o trecho é: “[...] a instituição de semelhante guardião da Constituição seria diametralmente oposta à consequência política do princípio da democracia”.

${ }^{7}$ Cumpre assinalar que tal resposta kelseniana ao caráter antidemocrático schmittiano é redigida como se pudesse ser rebatida a partir da análise do conceito de democracia em sua perspectiva liberal.

${ }^{8}$ Uma livre tradução sugerida para o trecho é: “A demanda de um custódio e defensor da Constituição é, na maioria dos casos, indício de situações críticas para a Constituição”.
} 
merecedora de seu empenho analítico e crítico, tal como fizera com Weimar. Nisto, portanto, sugerimos encontrar a apenas uma aparente defesa schmittiana da instituição de um guarda ou protetor da Constituição, pois este protetor, em verdade, nada mais seria do que em uma figura soberana travestida de formas democrático-legais, mas capaz de dispor do conteúdo constitucional ao seu livre arbítrio mediante a utilização de seu livre arbítrio jurídico pelas vias liberais, mas que em Schmitt recebe um alargamento ou extensão não previstos pela norma constitucional.

O desenvolvimento da hipótese deste texto inicia justamente com a apresentação e análise da intervenção do guardião da Constituição em um contexto em que, necessariamente, a crise se mostra aguda, e que nisto residiria a justificativa para a sua presença. Sem embargo, e em face do contexto da Presidência de Hindenburg, ao qual Schmitt sempre esteve preocupado em responder por meio de seus textos, e neste sentido seria necessário atentar à análise de Baño León, cuja interpretação é de que a resposta de Schmitt naquele contexto foi clara, e a sua opção apontava “[...] por una interpretación autoritaria de la Constitución de Weimar que otorgue al presidente unos poderes que permitan incluso prescindir del Parlamento” (BAÑO LEÓN, 2013, p. LIII). A hipótese do trabalho é precisamente a de que a teoria schmittiana apresenta um contexto de dramática crise como a weimariana, que facilmente congrega o político e o econômico para dele fazer emergir uma interpretação dos institutos jurídicos e políticos - Constituição incluída - na qual adquiria proeminência a figura do soberano.

O soberano seria o necessário operador político supremo, capaz de intervir a qualquer momento sobre o mundo jurídico, pois ele é o excelso poder que de nenhum outro deriva e que a nenhum outro se submete, emulando, assim, o próprio pouvoir constituant (ilimitado) - que não pode ser suprimido por nenhum poder ou norma - e não o pouvoir constitué (limitado), ou seja, que “Die souveräne Diktatur beruft sich auf den pouvoir constituant, der durch keine entgegenstehende Verfassung beseitigt werden kann” (SCHMITT, 2006, p. 136). ${ }^{9}$ Embora operando no território próprio deste segundo conceito, o fato é que o soberano se desempenha em Schmitt como se dispusesse da integralidade das competências do primeiro e, assim, Schmitt pode afirmar que “Souveränität ist höchste, rechtlich unabhängige, nicht abgeleitete Macht” (SCHMITT, 2009b, p. 26). ${ }^{10}$ Excelso e magnânimo poder, no contexto da obra schmittiana este poder encontra paralelo na teologia política, cujas linhas se mostram inspiradoras do perfil do soberano e, portanto,

\footnotetext{
${ }^{9}$ Uma livre tradução sugerida para o trecho é: “A ditadura soberana invoca o pouvoir constituant, que não pode ser suprimido por nenhuma Constituição oposta”.

${ }^{10}$ Uma livre tradução sugerida para o trecho é: “A soberania é o poder máximo, juridicamente independente, e não um derivado".
} 
examinaremos neste trabalho o movimento hermenêutico de Schmitt em ampliar a esfera de aplicação do art. 48 combinado com o seu parágrafo $2^{\circ}{ }^{11}$ Em verdade, Schmitt propôs na prática o desenho de seu conceito de ditador soberano apresentado em 1921 em Die Diktatur, mas que no Der Hüter der Verfassung é moldado de forma abrandada, como se se tratasse de um ditador comissário, mas cujas competências radicalmente abrangentes denotam tratar-se de outra espécie de projeto baseado em uma teoria política autoritária. Assim, embora Schmitt apresente este ditador sob a classificação de soberano comissário e fuja de apresentá-lo como ditador soberano, é isto que ele realmente é, e bem pensado sob a inspiração teológico-política schmittiana em sua inabordável e incontestável extensão de poderes. ${ }^{12}$

Portanto, quando Schmitt propõe que a soberania é o poder máximo e que, ademais, é juridicamente independente, e não uma derivação de qualquer outra instância, eis que, o que temos é um amplo e consistente pano de fundo teórico político para um conjunto conceitual bastante vasto em que resta explicitado o papel assumido em seu trabalho entre as relações entre direito e poder. ${ }^{13}$ É neste contexto que precisa ser lida a hipótese do conceito de guardião da Constituição, ${ }^{14}$ algo que propomos realizar de forma conectada aos seus extensíssimos poderes, o que permite uma leitura à luz do conceito de ditador soberano anunciado em 1922 em sua Politische Theologie. Propomos, portanto, que tanto o conceito de guardião da Constituição como o de ditador soberano de Schmitt

\footnotetext{
${ }^{11}$ Cabe apresentar inicialmente o texto do art. 48 e o de seu parágrafo segundo com o escopo de posicionar a discussão que terá lugar na sequência:

“ $1{ }^{\circ}$. Cuando un Land no cumpla los deberes que le imponen la Constitución o las leyes del Reich, el Presidente del Reich puede obligarle apelando a la fuerza armada.

2. Cuando en el Reich alemán se encuentren gravemente alterados o amenazados, el orden y la seguridad públicos, el Presidente del Reich puede adoptar aquellas medidas (massnahmen) que resulten necesarias para su restablecimiento, acudiendo a la fuerza armada si fuera preciso. A este fin, cabe suspender provisionalmente, en todo o en parte, los derechos fundamentales establecidos en los artículos 114, 115, 117, 118, 123, 124 y 153 de la Constitución”. (CONSTITUCIÓN DE WEIMAR, 2010, p. 203).

${ }^{12} \mathrm{O}$ exame desta questão é realizado aqui, necessariamente, tão somente por um dos diversos ângulos possíveis; qual seja, o de utilizar uma perspectiva histórica para analisar a concepção de guardião da Constituição que aparecerá em texto schmittiano em meados de 1929 pela primeira vez (em forma de livro em 1931) à luz de uma obra anterior, Politische Theologie, em março de 1922. O objetivo desta leitura do conceito de Hüter der Verfassung a partir de Politische Theologie é buscar as raízes do poder e das competências do guardião da Constituição no próprio conceito de soberano que Schmitt enunciara em sua obra de 1922.

${ }^{13}$ Neste sentido, é necessário alertar que o foco de nossa atenção está basicamente em três conceitos essenciais para compreender a posição mantida por Schmitt relativamente ao problema do guardião da Constituição; a saber, no da relação anunciada no texto entre direito e poder, mas, também, no da precedência do conceito do político sobre o jurídico e, por fim, no do conceito de estado de exceção.

${ }^{14}$ Esta leitura já fora proposta por Schmitt pela primeira vez em 1924 em texto incluído neste trabalho dedicado ao problema, a saber, "La dictadura del Presidente del Reich según el art. 48 de la Constitución de Weimar" (ver SCHMITT, 2013b), e retomado em forma de artigo bem mais desenvolvido em 1929, e receberia posterior e definitivo acabamento em seu livro de 1931, consagrando a sua interpretação do artigo 48 da Constituição de Weimar.
}

Revista da Faculdade de Direito - UFPR, Curitiba, vol. 60, n. 3, set./dez. 2015, p. 103-136 
se encontram conectados a uma teoria política específica e bem constituída, cujo viés explicativo é o aprofundamento das razões da ditadura como via de resolução para os problemas da democracia vigente na República de Weimar. Para fins de apresentação deste trabalho, portanto, primeiramente analisaremos o debate implícito no controle de constitucionalidade em Weimar que levou à oposição entre Schmitt e Kelsen para, momento seguinte, estruturar a explicação da posição de Schmitt por meio de sua teoria política.

\section{O CONTROLE DE CONSTITUCIONALIDADE NA CONSTITUIÇÃO DE WEIMAR: A POLÊMICA EM TORNO DO ART. 48, $2^{\circ}$}

Desnecessário sublinhar que o momento histórico em que foi desenvolvida expressiva parte da produção intelectual de Schmitt e de seus conceitos jurídicos entre a década de 1920 em Weimar e início da década de 1930 e, em especial, daqueles trabalhos aqui analisados, foram elaborados em um contexto sociopolítico de profunda comoção. As decisões políticas tomadas no âmbito da Constituição representavam perfeitamente a alta tensão da encruzilhada histórica experimentada naquele momento: decidir entre monarquia e república, decidir entre democracia e a ditadura de modelo soviético (DYZENHAUS, 2003, p. 77). Era o ano de 1919 na Alemanha e, em especial, no momento político soberano por antonomásia, a saber, aquele em que as grandes oposições se dão, e ali foi definida a República, em detrimento da ditadura do proletariado; a preferência pela democracia liberal-parlamentar, e não uma ditadura de época, similar à soviética.

Em tal contexto inalterado após a promulgação da Constituição de Weimar e de prolongamento de embates e radicalizações, Kelsen desenhou o quadro político habitado por extremistas de direita e de esquerda, igualmente radicais em seu rechaço a vida parlamentar e apoio às ditaduras (KELSEN, 2009, p. 90). As instabilidades, sem embargo, não foram superadas pelas graves decisões tomadas, e disto são excelentes exemplos os embates que se sucederam entre conservadores refratários à ordem republicana, restauracionistas monárquicos, sociais-democratas, liberais, socialistas e, em meio a todos e por eles distribuídos, a variável religiosa, dividida principalmente entre católicos e protestantes.

Em tal contexto a discussão sobre quem seria e em que extensão teria a competência para exercer o papel de guardião ou protetor da Constituição não era, portanto, tão somente um debate acadêmico (Doktorfragen), mas, antes de tudo, uma questão de inflexão prático-política relevante. Os próprios constituintes weimarianos, Hugo Preu $\beta$ à frente, haviam notado a importância do tema ao elaborar o art. 48, e a sucessão dos fatos lhes daria razão, mormente, pelas instabilidades políticas e econômicas derivadas da derrota ao final da Primeira Grande Guerra Mundial, agravadas 
pelas imposições de Versalhes, exemplo histórico de como um mau arranjo diplomático com um país vencido pode dar origem e vez a extremismos que, logo, se revelam tão nocivos quanto o precedente conflito bélico superado. ${ }^{15}$

Naquele contexto é necessário sublinhar a alta instabilidade do poder político, a alta voltagem dos conflitos e dos desarranjos internos que contava, por exemplo, sucessivas crises parlamentares, sendo prova disto o fato de que durante os primeiros cinco anos da República de Weimar terem ocuparam o poder cinco chanceleres e diversas coalizões de governo. A uma situação como esta é que Kelsen faz referência que muitos qualificavam como bancarrota ou agonia do parlamentarismo, algo com o que francamente não poderia concordar, senão nos termos de uma crise, todavia abordável (KELSEN, 2009, p. 90-91), embora não para críticos como Schmitt, para quem o parlamento não era, de modo algum, o locus capaz de produzir a vontade política estatal unitária, cuja representação era possível por meio da figura do Reichspräsident, capaz de organizar a vontade primitiva e unitária de caráter existencial que organizara a Constituição (SCHMITT, 2003, p. 10). Indubitavelmente, aquele era um período em que a crise ia sendo tomada já como regra e não mais como exceção. Sob tal marcha dos fatos, o conceito de guardião da Constituição estaria a operar em estreita conexão com o de estado de exceção, pois nele se verificariam as hipóteses de ameaça, risco e insegurança justificadoras de suspensão de direitos previstas no parágrafo $2^{\circ}$ do não menos célebre art. 48 da Constituição de Weimar. Sem embargo, muitas dúvidas, doutrinárias e políticas, restavam acerca de sua aplicação.

Sendo esta a percepção schmittiana em matéria teórico-política, resultaria bastante bem encaminhado o sentido de sua interpretação no debate constitucional que se seguiria na década de 1920. Naquele momento o debate no qual Schmitt se viu envolvido contra grande parte dos constitucionalistas alemães se deu em torno da interpretação do art. 48 e seus parágrafos, muito especialmente o $2^{\circ}$. A polêmica foi estabelecida em torno dos poderes do Reichspräsident para ditar as medidas (massnahmen) e a suposta limitação a estas medidas que resultariam impostas pela

\footnotetext{
${ }^{15}$ Neste momento é impossível avançar no tema, mas a atualidade da má condução política da crise grega se torna de referência indispensável, quando mais pelo fato de ser a própria Alemanha, hoje, o Estado que ocupa a posição de potência vencedora que antanho fora dos EUA, e a Grécia, a que fora da Alemanha, a sofrer as consequências de um acordo financeiro do qual, certamente, não mantém culpa exclusiva e excludente de seus contratantes financeiros credores, tal como, em seu momento, tampouco a Alemanha, enquanto Estado, poderia ter sido excluída das responsabilidades da Guerra. Sem embargo, em tais situações o que está em causa é a sobrevida do Estado e das pessoas, e desconsiderar este fato é simplesmente hipotecar o futuro dos envolvidos em prol da suposta salvação de um conceito de economia que não passa de, apenas, resguardar o interesse de um grupo muito restrito capaz de impor os seus conceitos; notadamente, banqueiros e rentistas vários.
} 
enumeração de direitos fundamentais referidos no parágrafo $2^{\circ}$ do art. 48. O referido artigo “Intervenção [do Reich] e situações de exceção” previa que

$1^{\circ}$. Cuando un Land no cumpla los deberes que le imponen la Constitución o las leyes del Reich, el Presidente del Reich puede obligarle apelando a la fuerza armada.

2. Cuando en el Reich alemán se encuentren gravemente alterados o amenazados, el orden y la seguridad públicos, el Presidente del Reich puede adoptar aquellas medidas (massnahmen) que resulten necesarias para su restablecimiento, acudiendo a la fuerza armada si fuera preciso. A este fin, cabe suspender provisionalmente, en todo o en parte, los derechos fundamentales establecidos en los artículos 114, 115, 117, 118, 123, 124 y 153 de la Constitución. ${ }^{16} 17$

Como se pode observar, o parágrafo $1^{\circ}$ do artigo 48 dispunha sobre o caso de que Estadosmembros (Länder) da Alemanha não cumprissem a Constituição ou as leis do Reich; então, nesta hipótese, o referido artigo atribuía competências extraordinárias ao Presidente do Reich para intervir, lançando mão das medidas (massnahmen) necessárias para o restabelecimento da ordem se necessário, recorrendo às forças armadas. No âmago desta disputa política havia um precedente judicial.

Muito embora a Constituição de Weimar não fosse absolutamente esclarecedora a respeito do objeto em disputa e fossem levantados argumentos sobre lacunas, o fato é que pelo menos desde o ano de 1925, em uma sentença datada de 4 de novembro, o Tribunal Supremo do Reich (Reichsgericht) firmara a ideia de que todo tribunal alemão tinha competência para realizar o controle de constitucionalidade em sua forma difusa. Naquele contexto ia sendo confirmada,

\footnotetext{
${ }^{16}$ Dada a importância do trecho, citamos no original alemão: "Der Reichspräsident kann, wenn im Deutschen Reiche die öffentliche Sicherheit und Ordnung erheblich gestört oder gefährdet wird, die zur Wiederherstellung der öffentlichen Sicherheit und Ordnung nötigen Maßnahmen treffen, erforderlichenfalls mit Hilfe der bewaffneten Macht einschreiten. Zu diesem Zwecke darf er vorübergehend die in den Artikeln 114, 115, 117, 118, 123,124 und 153 festgesetzten Grundrechte ganz oder zum Teil außer Kraft setzen”. Os artigos citados estabelecem, respectivamente, a começar pelo artigo 114, o direito à liberdade pessoal, à inviolabilidade de domicílio, ao segredo de correspondência, telégrafo e telefone, à liberdade de imprensa e expressão, à liberdade de reunião, à liberdade de associação e, por fim, à propriedade privada. Uma livre tradução sugerida para o trecho é: "Se a segurança e a ordem pública no interior do Reich estiverem severamente atacadas ou em perigo, o Presidente do Reich poderá tomar as medidas necessárias que conduzam ao restabelecimento da ordem, intervindo, se necessário, com o apoio das forças armadas. Para este fim, poderá temporariamente suspender, totalmente ou em parte, os direitos fundamentais previstos nos artigos 114 , 115, 117, 118, 123, 124 y 153”.

${ }^{17}$ Os outros três parágrafos do mesmo art. 48 previam:

“ $3^{\circ}$. Cuantas medidas (massnahmen) haya adoptado el Presidente del Reich en virtude de los apartados $1^{\circ}$ e $2^{\circ}$ de este artículo, deberán ser puestas sin demora en conocimiento del Reichstag. Quedarán sin efecto si así lo requiere el Reichstag.

$4^{\circ}$. Si la demora llegara a constituir un peligro, puede el Gobierno de un Land adoptar en su território las medidas (massnahmen) referidas en el apartado $2^{\circ}$. Estas medidas quedarán sin efecto a instancia del Presidente del Reich o del Reichstag.

5․ Los pormenores serán regulados por una ley del Reich” (CONSTITUCIÓN DE WEIMAR, 2010, p. 203).
} 
portanto, uma relação de direito-dever por parte do Tribunal Supremo do Reich. A ideia era corrente e se encontrava disseminada, a ponto de o próprio governo ter apresentado ao Reichstag um projeto de lei sobre o exame de constitucionalidade dos preceitos de direito do Reich. Esta sentença dizia literalmente que:

No conteniendo la Constitución del Reich ningún precepto por el que se sustraiga a los tribunales la decisión sobre la constitucionalidad de las leyes del Reich y se confíe a otro organismo determinado, debe reconocerse el derecho, y el deber del juez a examinar la constitucionalidad de dichas leyes (apud LOMBARDI, 2009, p. XXXI).

A importância de tal sentença é tão notável quanto óbvia. Passo seguinte, a intervenção schmittiana no tema viria em sentido absolutamente contraditório ao adotado por esta decisão judicial do Tribunal Supremo do Reich e, portanto, visando desconstituir esta apresentação institucional judiciária, cuja ação estava inserida em um ordenamento legal constitucional weimariana do qual Schmitt pretendeu em seu momento apresentar-se como defensor. ${ }^{18}$

À luz da Constituição de Weimar, a tese de Schmitt, de que o controle fosse desempenhado por uma instância política, haveria de defender-se com prévia argumentação da transferência de poderes do controle de constitucionalidade deste Tribunal Supremo do Reich (Reichsgericht) para outro órgão julgador, um tribunal independente, político, que, nos termos schmittianos, convergia com o Executivo. Em reforço à sua argumentação, Schmitt ancorou parte de sua crítica tentando desconstruir a ideia de que a esfera judicial seria a única apta à defesa da Constituição, e para tanto sustentou a ideia de que a instância judicial era abertamente antidemocrática. Com isto entreabria as portas para a sua teoria, ou seja, que “[...] über diesem gerichtlichen Schutz die sehr engen Grenzen jeder Gerichtlichkeit und die vielen anderen Arten und Methoden einer Verfassungsgarantie zu vergessen” (SCHMITT, 1996, p. 11), ${ }^{19}$ ou seja, que acima do Judiciário poderíamos encontrar outras e melhores opções, certamente políticas, para realizar a tarefa de defesa da Constituição. Este tipo de aproximação levada a termo por Schmitt permitiu que um conjunto de comentaristas entendesse que o autor havia desenvolvido uma linha interpretativa que permitiria classificar o seu trabalho em uma linha direta de comunicação com o autoritarismo (LUCAS VERDÚ, 1996, p. 301).

\footnotetext{
${ }^{18}$ No prefácio de Legalität und Legitimität, livro que escreve já bem depois do término da Primeira Grande Guerra Mundial, e publicado no ano de 1932 - portanto, já às vésperas da catástrofe hitleriana ter início -, Schmitt se apresenta como alguém que, naquela obra, realizara esforço derradeiro e denodado para proteger a Constituição de Weimar. Inobstante o juízo que se faça a respeito desta declaração de Schmitt, este é um livro extremamente importante para que possa ser realizada a análise da teoria constitucional de Schmitt, bem como o é, por suposto, a sua Verfassungslehre. Esta tarefa, sem embargo, foge do recorte do objeto neste momento.

${ }^{19}$ Para uma livre tradução do texto sugerimos: "[...] que acima desta defesa judicial existem muitos outros tipos e métodos de garantia da Constituição".
} 
Diversa dessa leitura de Lucas Verdú, também compartilhada por Estévez Araujo, Campderrich Bravo e Hasso Hofmann, é a de Franco de Sá e de Joseph Bendersky. Para ambos, a melhor interpretação é a de que Schmitt foi, a seu modo, um defensor da Constituição de Weimar. Bendersky sustenta que o autor não se perfilou entre aqueles que quiseram aumentar desmesurada e ilimitadamente os poderes do Presidente do Reich (Reichspräsident) senão que, mais precisamente, concebia travas institucionais ao poder soberano qualificado como meramente comissário, e este movimento argumentativo, pode-se supor, realizava-o baseado no parágrafo terceiro do art. 48, que submetia as decisões do Reichspräsident à avaliação do Parlamento. ${ }^{20}$ Bendersky (1989, p. 158) ancora parte de sua argumentação em defesa da postura constitucionalista schmittiana, ao afirmar que

[...] è di per sé evidente che non stiamo qui proponendo una competenza incontrolatta e illimitata del presidente del Reich [e] che i limiti attuali al potere eccezionale del presidente del Reich e l'attuale garanzia verso il suo potere risiedono nella autorità di controllo del Reichstag [...].

A leitura de Bendersky sobre a trava parlamentar prevista no parágrafo terceiro do art. 48 pode, de fato, ser aludida do ponto de vista formal em defesa de sua tese, mas poderia funcionar mais adequada e corretamente quando estivesse em causa pensar a posição dos pais da Constituição - de Preuß, por exemplo -, quando, em outro contexto, concebeu a íntegra das disposições do art. 48 e, naquele momento, o conteúdo do parágrafo terceiro bem poderia parecer uma trava suficientemente resistente para possíveis avanços arbitrários do Poder Executivo, concentrados no Reichspräsident pelo parágrafo primeiro do art. 48. Sem embargo, o problema de aplicar o mesmo argumento para Schmitt é que ele intervém em um momento em que ele próprio, já desde o ano de 1923, tecera as mais duras críticas ao Parlamento e, portanto, ao seu juízo, estava não apenas clara, mas claríssima, a incompetência técnico-política daquela casa legislativa alemã. Portanto, se realmente era assim, como Schmitt poderia, de forma congruente, interpretar o conteúdo do parágrafo terceiro do art. 48 como uma trava suficiente para eventuais atos arbitrários por parte do Reichspräsident?

\footnotetext{
${ }^{20}$ Especificamente, previa o referido parágrafo terceiro do art. 48 que: "Cuantas medidas (massnahmen) haya adoptado el Presidente del Reich en virtud de los apartados $1^{\circ}$ y $2^{\circ}$ de este artículo, deberán ser puestas sin demora en conocimiento del Reichstag. Quedarán sin efecto si así lo requiere el Reichstag” (LA CONSTITUCIÓN DE WEIMAR, 2010, p. 203).
} 


\section{O ART. 48: PODER, CONTROLE PARLAMENTAR E O CASO PREUBENCHSLAG}

Para Schmitt, a guarda da Constituição implica a disposição de competência e amplitude de poderes extensos o suficiente para a definição de critérios para o cumprimento do cometido constitucional de preservar a Constituição. Neste sentido o soberano também pode estabelecer os critérios para que tenha vez e lugar a suspensão da ordem constitucional e, passo seguinte, seja decretado o estado de exceção. Esta amplitude de poderes carrega consigo também a posse de livre critério para suspender o estado de exceção decretado, o que bem anuncia e prova que é um conceito que se esgota em si mesmo ou, como disse Schmitt, “[...] Grenzbegriff allein gerecht werden” (SCHMITT, 2009b, p. 13), que é um conceito aplicável à esfera extrema da vida política portanto, não pertencente a vida ordinária, mas, antes, típico do extra-ordinário. Sem embargo, isto contém uma contradição, pois, ainda em 1924, Schmitt apresentava o argumento de que a exceção era a própria condição de fundamentação da força da regra, ou seja, que "Vielmehr soll die Ausnahme die Kraft der Regel bestätigen” (SCHMITT, 2006b, p. 224). ${ }^{21}$

A contradição resta explicitada porque, com o apoio de Schmitt, logo a exceção foi tornada regra e, enquanto tal, perderia a condição de exceção por meio da qual Schmitt pretendia justificar a sua existência à parte do direito. Sendo assim, o condutor soberano do Estado em seu período de exceção seria capaz de intervir sobre o direito. Sem embargo, alegadamente, a retórica schmittiana indica que o Reichspräsident o faria sem empregar esforços para abolir a ordem jurídica, ou seja, que "Die Ausnahme setzt sogar die unveränderte Weitergeltung der Norm voraus, von der sie abweicht. Es gehört zum Begriff der Ausnahme, da $\beta$ sie eingreift, ohne aufzuheben und abweicht, ohne außer Kraft zu setzen” (SCHMITT, 2006b, p. 224). ${ }^{22}$ Schmitt pressupõe à exceção o período de absoluta normalidade, da qual o curso teria em algum momento se descolado, período conduzido pelos inimigos do Estado, contra os quais deve o soberano empenhar-se em combater por meio das medidas previstas no art. 48, 2º da Constituição de Weimar, de forma mais ou menos ampla. Em sua Die Diktatur Schmitt propõe a intervenção do ditador comissário, conceito sob o qual cobre a sua interpretação do referido art. 48, 2º cujo radical conteúdo é, em verdade, preenchido pela alta voltagem autoritária de um Reichspräsident recoberto de amplos poderes, na dimensão necessária requerida para o enfrentamento das situações de emergência, algo que poderia parecer razoável, mas não tanto quando tal juízo restasse exclusivamente encarregado ao referido Reichspräsident.

\footnotetext{
${ }^{21}$ Para uma livre tradução do texto sugerimos: “A exceção deve confirmar a força da regra”.

${ }^{22}$ Para uma livre tradução do texto sugerimos: “A exceção pressupõe, inclusive, a duração inalterada da norma de que ela se distancia. Pertence ao próprio conceito da exceção que intervenha sem abolir e que se distancie, mas sem deixar em suspenso a norma”.
} 
Relativamente a este objeto esta seção se ocupa centralmente da resposta schmittiana à questão que aparece em Wer soll das Hüter der Verfassung Sein? (1929). ${ }^{23}$ Nesta obra, a resposta schmittiana sobre a guarda da Constituição é direta. Contrariamente à proposta kelseniana, ela não deveria ser ocupada por setores da esfera jurídica, um órgão com competência específica, por alguma espécie de juiz ou tribunal. Para Schmitt, a guarda da Constituição é algo que pode ser reservado e resolvido de forma diversa à da ficção jurídica, ou seja, que “[...] so läßt sich die Frage nach dem Hüter der Verfassung anders beantworten als durch fiktive Justizförmigkeiten” (SCHMITT, 1996, p. 70). ${ }^{24}$ Costurando a sua crítica desde dentro da lógica do Estado democrático, Schmitt aponta para a gravidade de que o Estado democrático criasse um Tribunal especial dotado de competência de controle de constitucionalidade, pois estas são questões eminentemente políticas (HERRERA, 1994, p. 203), diversas da ficção jurídica e para além do caráter antidemocrático representado por sua operação tuteladora da Constituição pelas vias de uma burocracia instaurada para tal cometido. O caráter antidemocrático foi argüido por Schmitt como um argumento de fundo contra a outorga da competência de controle de constitucionalidade a qualquer Tribunal, pois constituem tão somente uma aristocracia de toga, distanciada da radicalidade democrática cujo eixo é político. Em seus termos, para Schmitt (2009b, p. 156),

Keine Justizförmigkeit könnte darüber hinwegtäuschen, da $\beta$ es sich bei einem solchen Staats- oder Verfassungsgerichtshof um eine hochpolitische Instanz mit Verfassungsgesetzgebungsbefugnissen handelte. ${ }^{25}$

Para Schmitt, portanto, o grau de politicidade do Judiciário deveria ser reconhecido enquanto tal, do que se poderia concluir sobre as limitações que a democracia formal e liberalburguesa supunha em sua dimensão legal, qual seja, que tal função política do Judiciário não seria imaginável em uma textura sociopolítica e legal realmente democrática, ou seja, que "Vom demokratischen Standpunkt aus wäre es kaum möglich, einer Aristokratie der Robe solche

\footnotetext{
${ }^{23}$ O problema central desta seção é, portanto, o da interpretação dos limites da competência do órgão ou instituição, a quem caberia definir a constitucionalidade em caso de (supostas) violações da Constituição de Weimar. Ao falar de defesa da Constituição de que estamos a tratar é, primeiramente, de uma violação, por ação ou omissão, ao seu texto, e, em segundo plano, a quem caberá protegê-la de tal violação. Nesta situação havia quem, como diz Kelsen, realizasse um reclamo pela proteção das normas constitucionais (cf. KELSEN, 1995, p. 4).

${ }^{24}$ Para uma livre tradução do texto sugerimos: “[...] a questão relativa ao protetor da Constituição pode ser resolvida de outra maneira, não se recorrendo a uma fictícia judicialidade”.

${ }^{25}$ Para uma livre tradução do texto sugerimos: "Nenhum formalismo judicial poderia encobrir o fato de que semelhante Tribunal de Justiça Política ou Constitucional viesse a ser uma instância política suprema com atribuições para formular preceitos constitucionais.
} 
Funktionen zu übertragen” (SCHMITT, 2009b, p. 155-156). ${ }^{26}$ Desde logo, esta posição sustentada por Schmitt logo mostraria a sua inconciliabilidade com a de Kelsen, proclive, por seu turno, ao triunfo da justiça constitucional. Orientando a sua reflexão sobre valores desde a prioridade do político, para Schmitt o decisionismo é que revelaria a capacidade jurídica de aplicação do bom direito (das gute Recht) a uma situação política controversa bem compreendida.

Nesta perspectiva assumida por Schmitt, não seria perdido o "ser" de todo movimento político (SCHMITT, 2009b, p. 8), enquanto que, por seu turno, o normativismo permaneceria aterrado no modo funcional típico de uma burocracia de Estado. ${ }^{27}$ Em seus termos, portanto, “[...] der Normativist in seiner Entartung das Recht zum bloßen Funktionsmodus einer staatlichen Bürokratie macht und der Dezisionist immer in der Gefahr steht [...]” (SCHMITT, 2009b, p. 8). ${ }^{28}$ Este risco imposto pelo normativismo kelseniano era associado à falência do ocaso liberal da República de Weimar que, em sua essência, era a entronização do movimento de despolitização típico do criticado Estado burguês. Inversa era a via decisionista schmittiana, sempre capaz de advertir sobre as ameaças inerentes a este cenário liberal-despolitizante, pois ali jaz o perigo, ou seja, que “[...] die Funktualisierung des Augenblicks das in jeder großen politischen Bewegung enthaltene ruhende Sein zu verfehlen [...]” (SCHMITT, 2009b, p. 8). ${ }^{29}$

A proposta de Schmitt, em resposta ao grande debate daqueles dias, era de que uma resposta de tal importância haveria de ser reservada à esfera do político. Em suma, do que se tratava era de que a Constituição era um documento político, e que sua concepção de democracia implicava que sua guarda não restasse distanciada do poder político mas, por certo, a saída totalitária de Schmitt não indicaria o Parlamento como tal titular, mas, antes, a figura do Presidente, o Reichspräsident, o chefe de Estado, como veremos na sequência.

Voltando ao texto constitucional, o que estabelece o parágrafo terceiro do art. 48 é a obrigação do Reichspräsident de submeter ao Parlamento quantas medidas (massnahmen) tenha

\footnotetext{
${ }^{26}$ Para uma livre tradução do texto sugerimos: "Isto significaria algo apenas imaginável desde o ponto de vista democrático: transladar tais funções à aristocracia da toga”.

${ }^{27}$ Schmitt destacava, precisamente, que a ruptura com esta ordem tinha vez e lugar com o Estado de exceção, pois ali "In der Ausnahme durchbricht die Kraft des wirklichen Lebens die Kruste einer in Wiederholung erstarrten Mechanik" (SCHMITT, 2009b, p. 21). A tradução livre sugerida para este texto é: "Na exceção é que a força da vida real rompe a crosta de uma mecânica cristalizada na repetição".

${ }^{28}$ Para uma livre tradução do texto sugerimos: “[...] o pensamento normativista, em sua descaracterização, vem a transformar o direito em um mero modus funcional de uma burocracia de Estado, o do princípio decisionista corre sempre o perigo de perder, por meio da funcionalização do momento, o 'ser' que repousa em todo o movimento politico $[\ldots] ”$.

${ }^{29}$ Para uma livre tradução do texto sugerimos: “[...] o princípio decisionista corre sempre o perigo de perder, por meio da funcionalização do momento, o 'ser' que repousa em todo o movimento politico [...]”.
} 
adotado por força de sua competência para tanto com base nos parágrafos $1^{\circ}$ e $2^{\circ}$ do mesmo art. 48, do que deriva a competência, prevista in fine, que o Reichstag poderia retirar a validade das mesmas se assim o requeresse ao Poder Executivo, por reputar adequado.

Neste contexto legal-constitucional do art. 48, a rigor, a interpretação do argumento de Schmitt, recuperado por Bendersky, sugere principalmente que tenhamos uma defesa oculta e estratégica do alargamento desmesurado dos poderes do Reichspräsident por meio de uma manobra de socavamento das instituições republicano-democráticas, ao atribuir a um Reichstag fraco uma competência para a qual não dispunha de energia suficiente. Segundo a descrição do próprio Schmitt, a debilidade do Parlamento era tal que não era possível supor que ele estivesse disposto a realizar o bloqueio de eventuais atos arbitrários praticados pelo Reichspräsident por meio da adoção das medidas (massnahmen) previstas nos parágrafos $1^{\circ}$ e $2^{\circ}$ do art. $48 .^{30}$ Idêntica análise histórica sobre a debilidade parlamentar é compartilhada por Dyzenhaus (2003, p. 74), para quem "By 1930, the political situation virtually excluded the possibility of Parliament asserting control over the President and thus a significant role for Parliament seemed ruled out”.

Como se nota, a aplicação empírica do artigo 48 teve lugar em momento de transcendental importância na vida alemã, em 10 de outubro de 1932 em Leipzig, e convém sublinhar que isto ocorreu a escassos quatro meses da ascensão de Hitler ao poder na Alemanha, o que se deu em 30 de janeiro de 1933. Naquele momento, estava sob juízo a disputa entre o Land da Prússia, governada por uma coalisão de partidos que oscilavam ao redor do Zentrum católico e, por outro lado, o Reich, representado pelo seu advogado, o ilustre jurista Carl Schmitt - aliás, conhecido católico - no caso que ficaria conhecido como Preußenschlag. Este caso foi o marco nos tribunais da disputa teórica entre Schmitt e Kelsen, pois ali ficou determinada a defesa de duas teses a respeito de quem seria o defensor da Constituição (o Chefe de Estado?) e qual a extensão dos poderes e competências do guardião da Constituição.

\footnotetext{
${ }^{30}$ Do ponto de vista técnico-jurídico a crítica de Albanese é bastante acurada. Indica o autor que o art. 48 não poderia atribuir a autorização ilimitada ao Presidente do Reich, como sugeria Schmitt, inversamente, à grande parte dos constitucionalistas alemães. Se isto fosse assim, então, indica Albanese que "In questa maniera il presidente del Reich o il Reichstag diventerebbero depositari di un pouvoir constituant e la costituzione si ridurrebbe ad elemento estremamente provvisorio e precario dell'ordine esistente. Il presidente del Reich potrebbe assumere tali poteri in virtù di un mandato della Assamblea nazionale costituente, se questa fosse intesa come depositaria di un pouvoir constituant e il presidente como un comisario" (ALBANESE, 1996, p. 147). Desde logo, esta não parece ser a melhor tradição constitucional, que nada mais delega ao poder constitucional derivado do que um poder revisional, mas não fundador ou soberano, reservado a outro momento em que o poder constituinte volte a ser exercido pelo poder político constituído para tal finalidade legisladora fundamental. Deste modo, portanto, converge Albanese ao sustentar que "Il Reichstag invece, essendo pouvoir constitué, non sarebbe evidentemente in grado di conferire simili commisioni illimitate” (ALBANESE, 1996, p. 148).
} 
Efetivamente, a tese de Schmitt era de que o guardião era o Chefe de Estado, e isto, para Schmitt, dificilmente poderia ter sido mais claro do que ao dizer que "Nach dem vorliegenden Inhalt der Weimarer Verfassung besteht bereits ein Hüter der Verfassung, nämlich der Reichspräsident” (SCHMITT, 2009b, p. 158). ${ }^{31}$ Com base no art. 48, ele poderia intervir nos Länder, tal como reclamado pelo Governo de von Papen no caso da Prússia, enquanto que, por outro lado, a imensa maioria dos teóricos do direito constitucional do período, Kelsen incluído, reputavam que, até então, o que tinha ocorrido era uma violência contra o estatuto dos Länder por meio do frequente abuso legislativo do Reichspräsident por meio de decretos.

\section{A TEORIA POLÍTICA: AUTORITARISMO E TEOLOGIA}

Nesta seção pretendemos apresentar os traços essenciais da teoria política schmittiana sustentada a partir da hipótese de sua vinculação autoritária. O primeiro passo para isto é observar a forma do Poder Executivo no trabalho de Schmitt, cujo perfil e desenho institucional de sua inserção foi eminentemente autoritário. Isto se deve menos às debilidades e problemas históricos que realmente eram enfrentados pela República de Weimar do que por uma convicção de fundo em matéria de teoria política da qual partiu o seu pensamento jurídico. Se é mesmo fato que a política precede o direito, também em Schmitt a sua teoria política de corte autoritário determinou o sentido de sua construção conceitual no campo jurídico e, em especial, constitucional. E se é mesmo certo que a decisão judicial constitucional é uma decisão política, e que esta não está baseada em nada além de uma pura vontade, e não em uma pura norma, então, o que temos, ao fim e ao cabo, é uma referência política e, por fim, Schmitt seria congruente ao sustentar que “Ogni concetto politico è un concetto polemico” (SCHMITT, 2001a, p. 91) e, assim, todo conceito político não passaria da expressão de uma preferência.

Inobstante o endereçamento autoritário de sua teoria política, Schmitt soube recrutar e mobilizar referenciais conceituais como Maquiavel e Hobbes, mas também o liberal Benjamin Constant, para a sua criação conceitual jurídica. Neste sentido, por exemplo, buscou em forças tanto do pensamento clássico (antirrevolucionário) da própria tradição liberal presente em Benjamin Constant em sua concepção do pouvoir neutre, bem como da tradição teológica localizável em

\footnotetext{
${ }^{31}$ Uma livre tradução sugerida para o trecho é: “Segundo dispõe o conteúdo da Constituição de Weimar, já existe um defensor da Constituição, ou seja, o Presidente do Reich”.
} 
Donoso Cortés já em seu período conservador de final de vida. ${ }^{32}$ Da concepção de pouvoir neutre de Constant, Schmitt acreditou poder extrair e aplicar conceitos tais como o de neutralidade para a intervenção nos conflitos e embates políticos. Para pensar a estrutura do poder político Schmitt também buscaria referenciais na imagem da figura toda poderosa do monarca absoluto, inspirada em figura paterna cuja autoridade remetia ao instituto da patria potestas romana, e cujo calço teológico era também importante. Neste sentido é que Schmitt recorreu a certa tradição teológica presente em Donoso Cortés, de quem reinterpretou o conceito de infalibilidade papal que, por vias tortuosas, transpôs para o campo da teoria política e, passo seguinte, para a sua teoria jurídica, ao estruturar o conceito mítico de Führer.

Schmitt considerou que a época das monarquias absolutas havia acabado, e que, como admitira Donoso Cortés, já não havia monarcas daquela estirpe necessária para dar curso ao programa político monárquico. ${ }^{33}$ Sem embargo, o modelo, baseado em seus referenciais legitimadores transcedentais, este sim, seria ainda capaz de sobrevida. Neste sentido, Schmitt realizou o movimento de translado dos elementos componentes do conceito de monarquia absoluta para o Estado moderno, mesmo que republicano. ${ }^{34}$ Nas mãos de Schmitt não foi de difícil realização a tarefa de emprestar a tal modelo político de Estado uma estrutura de poder singular, e não apenas dotá-la de uma autoridade, do tipo que liberais como Kelsen poderiam estar dispostos a admitir, pois para estes deveria vigorar uma versão moderada e controladora do poder, pois aqui estaria mesmo o cerne de seu concerto de boa sociedade e de Estado (KELSEN, 2009b, p. 41).

Tendo em mente o modelo hierárquico das monarquias absolutas que remete ao modelo hierárquico da Igreja Católica, Schmitt tinha pendente o efeito unificador que as monarquias

\footnotetext{
${ }^{32}$ Donoso Cortés dedicou importante espaço de seu trabalho de maturidade que compreende basicamente os últimos seis anos de sua vida ao conceito de ditadura; em especial, por meio de seu Discurso sobre la dictadura (ver DONOSO CORTÉS, 1954), recepcionado por Schmitt, bem como em sua crítica à teoria liberal que, por certo, veio sendo elaborada progressivamente desde a década de 1840.

${ }^{33}$ Ao analisar a posição do monarca no pensamento schmittiano é possível concluir que o autor tinha em mente a figura que ocupara o poder durante o século XIX. Sem embargo, reconhecia que aquele perfil de caudillo se encontrava em estado histórico de degradação (cf. SCHMITT, 2003, p. 283).

${ }^{34}$ Schmitt configurou o exercício de um poder desmesurado na esfera pública como se fosse nada mais do que o de um pater familias à busca de uma noção específica de bem privado para os seus, legitimado pela homogeneidade familiar de uma linha de consanguinidade, que, supostamente, seria autorizadora do exercício de tal poder paterno para definir os rumos que cada um dos membros da família deveriam tomar em suas vidas, com a orientação necessária para o alcance dos fins do próprio clã. No campo político, inversamente, a justificativa para a busca do bem precisa encontrar no campo retórico-discursivo o poder de persuasão necessário para a formação de consensos mínimos e provisórios. Schmitt posiciona o exercente do dominus político em seu território como se fosse a figura do benevolente pai de família ou de uma transcendente aplicação da todo-poderosa figura divina, o que, por suposto, não supõe que Schmitt desconhecesse nem a perfeita divisão entre estas duas órbitas e nem as consequências de relegá-las a segundo plano (cf. SCHMITT, 2003, p. 285-286).
} 
produziram na Idade Média para superar a típica descentralização de poder daquele período, pluralidade de poderes novamente presente em formatação político-partidária no cenário político weimariano cuja alta densidade conflitiva Schmitt procurou enfrentar. Com a finalidade de recobrar um modelo político unificador do poder em face do esfacelamento da autoridade do II Império de Guilherme II, Schmitt admitiu com toda a clareza que, na vida republicana, “Dieser Staatspräsident ist der republikanisierte Monarch der parlamentarischen Monarchie [...]” (SCHMITT, 2003, p. 290) ${ }^{35}$, ou, como propõe Albanese, trata-se de que a função do “[...] presidente del Reich sia analoga a quella di un capo monarchico dell'Esecutivo" (ALBANESE, 1996, p. 145), o que remete à tese de fundo de que o Reichspräsident estaria substituindo os poderes que antanho haviam sido desempenhados pelos imperadores (ALBANESE, 1996, p. 145), ou seja, verdadeiramente toma posse das atribuições do imperador (SCHMITT, 2003, p. 292).

A similaridade entre ambos era também reconhecível no âmbito das competências reconhecidas ao Presidente do Reich (Reichspräsident) pela Constituição de Weimar, algo que, para Schmitt, tornava-se a prova final da analogia sugerida por ele. Schmitt enumerou uma série de competências que demonstrariam o paralelo entre a figura do monarca e a do Presidente do Reich; entre elas, os artigos 179, I, da Lei sobre o poder provisório do Reich, de 10 de fevereiro de 1919, e, ainda, a lei transitória de 4 de março de 1919 (SCHMITT, 2003, p. 292). O resumo disto era a conclusão de Schmitt acerca da competência do Reichspräsident para o exercício do controle de constitucionalidade, movimento que, na leitura kelseniana de Herrera, teria sido comprobatório de uma aspiração schmittiana à formatação de um constitucionalistamo monárquico (HERRERA, 1994, p. 219) ou, no mínimo, sugeriríamos, de um modelo que se mantivesse fiel ao das monarquias do século XIX e, portanto, de um viés constitucionalista bastante mitigado, na medida em que incapaz de estabelecer limites mais precisos aos governantes.

Isto aponta que o perfil de monarca em que Schmitt buscava referência para a sua obra estava relacionado a um poder político de ordem transcendente e que, por sua condição, era inconteste. Neste aspecto, portanto, cabe ressaltar a perspectiva de interpretação teológica sobre o Reichspräsident que sugerimos realizar neste trabalho. Novamente, neste aspecto da teoria política schmittiana é possível entrever as reverberações de seu diálogo com o teórico espanhol Donoso Cortés, cuja formação e obra voltadas ao catolicismo eram reconhecidas por Schmitt ${ }^{36}$ e formadoras

\footnotetext{
35 Uma livre tradução sugerida para o trecho é: “Este Presidente é o monarca republicanizado da monarquia parlamentar”.

${ }^{36}$ A propósito, mesmo Carl Schmitt foi formado em lar católico, e desde cedo não consta que houvesse sofrido dúvidas quanto à sua fé, e nem mesmo durante sua vida.
} 
de uma perspectiva bastante marcante em sua obra; catolicismo que, destaca Habermas (1998, p. 127), também seria igualmente impactante na obra de Heidegger. ${ }^{37} \mathrm{O}$ elo entre uma concepção do divino e sua relação com o poder terreno presente em Donoso Cortés, embora fortemente vinculado com a questão do poder divino sobre uma natureza humana má, termina por encontrar em Schmitt seu escoadouro ideológico natural a partir das vias conservadoras e autoritárias assumidas pelo espanhol em meados do século XIX. É certo, porém, que a teoria elaborada por Donoso Cortés não teve em vista o mesmo desenvolvimento e aplicação prática realizada por Schmitt.

À diferença de Donoso Cortés, para Schmitt era necessário encontrar um mecanismo para afirmar um poder total e, aqui, inspirado, certamente, na “mobilização total” (totale mobilmachung) jüngeriana. O regresso e a releitura de argumentos tais como aqueles postos por Donoso Cortés para reafirmar o poder da divindade eram extremamente úteis para Schmitt, a ponto de em vários momentos ser possível encontrar trechos no trabalho do espanhol que são facilmente interpretáveis como nucleares no pensamento de Schmitt. Exemplificativamente, um destes pontos diz respeito à questão da unidade da diversidade na figura de um só (Deus). Para Schmitt, esta possibilidade da legítima reunião do múltiplo no uno, da complexidade que a diversidade enseja na figura de um só, era demasiado útil, embora fosse necessária a realização de um movimento teológico político - qual seja, o de transpor o conceito de sua dimensão teológica (transcendência) para a política (imanência), pois, nesta última, seria então possível constituí-lo na figura de um Führer. ${ }^{38}$

Esta leitura teológica do político permite a realização de uma aproximação entre a posição do monarca absoluto, cujos poderes se encontravam fundados na divindade, e, por outro lado, a posição do Reichspräsident, bem como, posteriormente, a do próprio Führer. Estas posições apresentam com maior vigor o seu processo de progressiva convergência, e a apresentação de relativa similaridade, quando Schmitt escreve que o monarca se encontra em posição acima da ocupada pelos partidos, ou seja, que “[...] des Monarchen beruht dann vor allem darauf, daß er über den Parteien steht” (SCHMITT, 2003, p. 286) ${ }^{39}$; e ao sobrepor o monarca a eles, Schmitt termina

\footnotetext{
${ }^{37}$ Esta aproximação schmittiana ao catolicismo por meio de Donoso Cortés remete, em verdade, a uma trilha aberta para uma crítica da pós-modernidade, aspecto que não será possível seguir neste momento.

${ }^{38}$ Este contato e as ideias que Schmitt parece nele buscar para fortalecer as suas teses jurídico-políticas encontraram boa expressão ao realizar uma síntese das fundamentações principais das monarquias, a saber: $a$ ) a ideia de um Deus pessoal e b) a ideia de pai (cf. SCHMITT, 2003, p. 286). De fato, quando Schmitt emprega seu intelecto à construção dos fundamentos teóricos do nacional-socialismo ele irá se socorrer em algumas destas ideias na construção do mito do Führer, cuja onisciência e bondade não poderiam ser desconsideradas no momento em que se lhe entregava o poder total.

${ }^{39}$ Uma livre tradução sugerida para o trecho é: “A posição do monarca se baseia, sobretudo, em que se encontra por cima dos partidos”.
} 
por realizar uma perspectiva muito importante do ponto de vista da democracia - a saber, inverter um dos preceitos mais bem acabados e justificados (por Kelsen, inclusive), acerca da centralidade dos partidos e similares, para a organização de uma vida política que denominaríamos como avessa às mil faces que o autoritarismo pode assumir.

Schmitt retoma a ideia de Benjamin Constant ${ }^{40}$ sobre um pouvoir neutre monárquico, e sobre isto Dotti (2008, p. 310) chama atenção para o papel que o modelo de Constant acerca do monarca constitucional exerceu na situação alemã do período imediatamente posterior ao da Primeira Grande Guerra Mundial. Plenamente inserido neste contexto, Schmitt emprega esforços em transladar tal referencial teórico à ordem republicana, muito embora tortuosamente e sob chuva de críticas, como aquelas bastante consistentes advindas de Kelsen. Este poder neutro era entendido como se pudesse operar como uma entidade especial; ou seja, que

Er wird eine neutrale Gewalt, ein pouvoir neutre, ein unsichtbares, alle Gegensätze und Reibungen zwischen den verschiedenen staatlichen Tätigkeiten und Funktionen ausgleichendes, temperierendes und moderierendes Moment, ein invisible modérateur (SCHMITT, 2003, p. 287). ${ }^{41}$

Em verdade, contudo, este exercício da moderação política estava longe do que Schmitt desenhava como perfil do Poder Executivo, carregado de competências que transcendiam os limites legais e avesso a controles por parte tanto do direito como das instituições políticas.

\section{SCHMITT REPUBLICANO: ESTABILIDADE E MONARQUIA}

A figura do monarca posicionado como mediador de conflitos foi interpretada enquanto congruente com uma concepção de poder político capaz de representar a unidade política, e isto ocorreria por meio da figura do Chefe de Estado (SCHMITT, 2003, p. 288-289). A esta figura se encontraria infraposta a população, alheada da função de controladora política, pois, a rigor, Schmitt resolve no Reichspräsident a unidade representativa popular a partir da função política soberana exercida pela Assembleia Constituinte de Weimar. Schmitt pretendia confirmar esta configuração política como a da afirmação de uma democracia (SCHMITT, 2003, p. 291). É que, e bem convém reafirmá-lo, a interpretação de Schmitt, baseada na Constituição de Weimar, residia na

\footnotetext{
${ }^{40}$ Sua dívida com Constant é confessa em trecho em que remete a origem desta neutralidade do poder monárquico à monarquia liberal pensada pelo autor francês (cf. SCHMITT, 2003, p. 287). Um de seus comentaristas igualmente ressalta que Constant teria exercido um "influjo fundamental” (DOTTI, 2008, p. 310).

${ }^{41}$ Uma livre tradução sugerida para o trecho é: "Se converte [o Rei] em um poder neutro, um pouvoir neutre, uma entidade imperceptível que aplaina, ameniza e modera todas as contraposições e friç̧ões entre as diversas atividades e funções do Estado".
} 
atribuição de competências para o Reichspräsident guardar a Constituição enquanto representante da unidade da nação, sem alternativa, pois “[...] il garante dell'ordinamento costituzionale no può essere una emanazione del potere giudiziario, come ad esempio una corte costituzionale; tale compito, invece, può spettare solo al presidente del Reich” (ALBANESE, 1996, p. 44).

Esta competência, atribuída com exclusividade ao Reichspräsident, finalmente traduz uma particular posição de Schmitt sobre a democracia, cujo conteúdo básico o conecta ao da realização Constitucional segundo a noção de substância a partir de sua unidade homogênea e indivisível prevista no art. $1^{\circ}$ da Constituição de Weimar, segundo o qual era o povo quem concedia a si mesmo os dispositivos jurídico-políticos constitucionais, sendo esta uma radicalização laica do preceito bíblico segundo o qual todo o poder provém de Deus, ou seja, "Non est enim potestas nisi a Deo” (Romanos, 13, 1). A apropriação laica deste conceito teológico e sua migração para a teoria política permitiu a Schmitt detectar onde verdadeiramente residia a existência política do povo alemão, ou seja, que

Eine Verfassung beruht nicht auf einer Norm, deren Richtigkeit der Grund ihrer Geltung wäre. Sie beruht auf einer, aus politischem Sein hervorgegangenen politischen Entscheidung über die Art und Norm des eigenen Seins. Das Wort „Wille” bezeichnet [...] das wesentlich Existentielle dieses Geltungsgrundes (SCHMITT, 2003, p. 76). ${ }^{42}$

Nesta leitura schmittiana da Constituição como decisão política reside a sua noção essencial. Para Schmitt é, portanto, o elemento político, e não a norma, o ponto em que a Constituição se apoia, sendo a decisão que a funda tomada com base em uma decisão existencial de um ser político (SCHMITT, 2003, p. 76). Trata-se de que, como diz Franco de Sá, “[...] o próprio direito não pode efetivar-se sem que seja sustentado por um poder político que, sendo a expressão de uma ordem política concreta, surja como livre de qualquer circunscrição jurídica” (FRANCO DE SÁ, 2012, p. 89). Portanto, a partir disto se estrutura a interpretação constitucional, que precisaria ocorrer sobre esta base unitária e homogênea que a constituíra, o que levaria Schmitt a afirmar que

Die geltende Reichsverfassung hält an dem demokratischen Gedanken der homogenen, unteilbaren Einheit des ganzen deutschen Volkes fest, das sich kraft seiner verfassunggebenden Gewalt durch positive politische Entscheidung, also durch einseitigen Akt, selbst diese Verfassung gegeben hat (SCHMITT, 1996, p. 63). ${ }^{43}$

\footnotetext{
${ }^{42}$ Uma livre tradução sugerida para o trecho é: "Uma Constituição não se apoia emu ma norma cuja justiça seja fundamento de sua validade. Ela se apoia em uma decisão política surgida de um Ser politico acerca do modo e forma do próprio Ser. A palavra "vontade” denuncia [...] o essencialmente existencial deste fundamento de validade".

${ }^{43}$ Uma livre tradução sugerida para o trecho é: "A Constituição vigente no Reich afirma a ideia democrática da unidade homogênea e indivisível de todo o povo alemão que, em virtude de seu poder constituinte, deu a si mesmo tal Constituição mediante uma decisão política positiva, ou seja, mediante um ato unilateral”.
} 
À base desta argumentação dos poderes do Reichspräsident, portanto, Schmitt colocava a posição política soberana de todo o povo alemão, ao outorgar-se de forma soberana aquele texto weimariano. O poder do Presidente do Reich (Reichspräsident) apresentava-se, assim, não exatamente como o de um dirigente político, mas, antes, como o do executor de uma instância mediadora, um árbitro que exerceria uma espécie de poder modérateur, conciliando as partes (SCHMITT, 2003, p. 351), muito embora a teoria política schmittiana aponte para a atribuição de poderes que permitiriam que esta mediação fosse realizada a fórceps e com uma ilimitação de poderes que transcendia com sobras a medida da responsabilidade e da prudência democráticolibertária.

É sabido que Schmitt não se empenhou em ocultar todo o seu desapreço quanto ao potencial político da representação popular e, por conseguinte, do parlamento. Schmitt substituiu esta noção de valor da representação por uma instituição concentradora de tal capacidade que, outrora, havia se consolidado na ideia de que o monarca enfeixava poderes. Esta era uma ideia passível de atualização por meio da reinterpretação das competências do Reichspräsident, agora guardião da Constituição, dotado de plenos poderes, legitimando-os por meio da chamada unidade política, uma vez que apenas ele era o representante da homogeneidade do povo alemão construída no momento fundacional por meio da Assembleia Constituinte. Era o Reichspräsident, portanto, o único capaz de realizar tal finalidade, e não uma corte judicial, pois o conteúdo das decisões constitucionais são marcadamente políticos (ALBANESE, 1996, p. 45). A independência do Reichspräsident vinha a calhar e, ademais, lhe favorecia o fato de que lhe fosse oferecida por um liberal arrependido - Constant -, ${ }^{44}$ algo que fazia diminuir o impacto dos críticos quanto ao viés totalitário que o pensamento político e jurídico schmittiano foi adquirindo.

Embora voltado à consecução de uma estrutura estatal autoritária, Schmitt não desce à procura de apoio para sua teoria nos argumentos das monarquias absolutas mas, antes, dedica atenção à teoria das monarquias constitucionais, permanecendo alerta para o fato de que as monarquias haviam perdido em grande parte sua potestas, embora mantivessem sua auctoritas, devido ao triunfo histórico da restrição de poderes imposta pelo constitucionalismo, que levara à máxima de que Le roi règne, mais il ne gouverne pas, justo como descreve Schmitt: “[...] mit Recht,

\footnotetext{
${ }^{44}$ Em que pesem as possíveis contraditoriedades de Constant, é fato que observamos a contradição de que o grande teórico do decisionismo do século XX encontre argumento central para sua filosofia política em um autor tão ligado ao liberalismo clássico e ademais, como assinala Dotti, de uma figura de destaque da tradição romântica (DOTTI, 2008, p. 310), movimento também abertamente contestado por Schmitt desde os seus primeiros e mais célebres escritos. Isto, contudo, não impedirá que o nosso autor critique todo o veio liberal e parlamentar presentes em Constant, como bem destaca Dotti (2008, p. 310).
} 
als der Monarch zwar alle Macht (potestas) verlieren, aber als Autorität weiterbestehen und deshalb auch die eigenartigen Funktionen einer „neutralen Gewalt” besonders gut ausüben kann” (SCHMITT, 2003, p. 290). ${ }^{45}$

A restrição do poder monárquico encontrou em Schmitt um leitor atento para, especificamente no caso francês, imputar todos os dissabores. Supostamente, seria este frequente movimento de ascensão e queda dos monarcas na Europa o causador de tantos dissabores à população, seduzida pelas promessas republicanas e suas garantias de maior estabilidade institucional. ${ }^{46}$ A respeito da estabilidade como valor político, esta é noção tão presente no maduro Donoso Cortés quanto em sua apropriação conservadora-autoritária schmittiana. Em que pesem os sobrados motivos de ambos para manterem a guarda alta contra as instabilidades dos períodos históricos que lhes tocaram viver, sem embargo, vale a pena recordar a certeira ideia de Larmore acerca de que "Stability is not the ultimate value by which a political system is to be judged. Justice is a more important political value, though stability is itself often a sign of justice” (LARMORE, 1997, p. 188). O fato é que a priorização do valor estabilidade implica a colocação em segundo plano do valor realmente orientador de uma sociedade, tais como este da justiça bem destacado por Larmore. Certamente, a estabilidade é um das condições-meio para que seja possível a realização de uma série de valores, mas, sem embargo, o só fato de centralizar atenção na eliminação de quaisquer eventuais trepidações e riscos políticos implica, por si só, uma desestabilização superlativa; qual seja, a inviabilização das vias de acesso à realização da telos social, ou seja, de valores como a justiça, algo que, no caso de Schmitt, não chegou a alcançar posição em sua teoria jurídica.

Mas, se a estabilidade foi posicionada como um valor central na teoria política schmittiana, ela foi logo projetada sobre a sua teoria jurídica com o fito de se adequar a conceitos e institutos jurídicos específicos. Portanto, era necessária uma forte concepção de poder político que lhe pudesse assegurar em sua condição de valor jurídico inspirador de certos institutos. Se a monarquia e o seu poder supremo eram pensados, em Donoso Cortés, enquanto expressão do poder transcendente na terra, Schmitt não articula a sua reflexão pela via da realização temporal de valores

\footnotetext{
${ }^{45}$ Uma livre tradução sugerida para o trecho é: “[...] com razão, tanto que o monarca perde, é certo, todo poder (potestas), mas pode seguir existindo como autoridade e exercer muito bem as funções peculiares de um 'poder neutro'. ${ }^{46}$ Contudo, em suas linhas, Schmitt não parece muito convencido, se não dos valores republicanos em si mesmo, ao menos da forma republicana que viria a ser adotada em Weimar. Quiçá sua erudição, aliada à vivência e à aguda observância dos acontecimentos de seu tempo, tenham-no conduzido, com bastante apoio em seu conservadorismo católico (sua teologia política e a proximidade com Donoso Cortés são bons exemplos disto), a sustentar posições que, em outro momento, talvez tivesse tomado com maior prudência.
} 
transcendentes, mas tão somente por um modelo de hierarquia de poder. Deste modo, Schmitt realiza, por exemplo, movimento de aproximação aos argumentos do conservadorismo de Stahl sobre a monarquia constitucional prussiana. Segundo Julius Stahl (1802-1861), o que estava em causa relativamente à monarquia era que "Danach liegt das Wesen der konstitutionellen Monarchie darin, da $\beta$ der konstitutionelle Monarch noch eine wirklich Macht hat [...]” (SCHMITT, 2003, p. 289), ${ }^{47}$ e que em Weimar, como diz Albanese, seria traduzido juridicamente como um “[...] monarca repubblicanizzato della monarchia parlamentare [...]” (ALBANESE, 1996, p. 145).

Esse genuínio poder ao qual Stahl faz referência tem uma característica bastante própria e familiar ao texto político schmittiano; qual seja, que a determinação do mundo político está articulada em torno da exclusiva vontade do monarca, em detrimento de toda a organização política ao seu redor, uma vez que, não obstante a crise política de meados do século XIX, eis que “[...] sein persönlicher Wille noch etwas gilt und nicht im Parlament aufgeht. Er bleibt 'durch' die feste Sicherung seiner Befugnisse ein unterschiedener selbständiger Faktor der Staatsgewalt” (SCHMITT, 2003, p. 289). ${ }^{48}$ Se Schmitt realmente pode estar de acordo com Stahl, então, a figura do monarca age consoante uma vontade cujas origens estão localizadas em um ponto além das dobras do Estado e de suas instituições. A partir disto Schmitt pode pensar o valor da estabilidade enquanto unidade ou homogeneidade, ou seja, ausência de contradições e oposições políticas, vetor teórico-político orientado em sentido contrário ao das mais caras teses pluralistas do liberalismo.

Este argumento de Stahl, novamente retomado por Schmitt, auxiliar-lhe-ia em muito na defesa de um modelo de Estado fortemente autoritário, de poderes concentrados na figura do Poder Executivo. Schmitt necessitava de uma teoria política que ambicionasse a constituição de um Executivo forte, mas que operasse no âmbito do constitucionalismo, para que o diálogo com os dias republicanos de Weimar pudessem ter seu curso ordinário. Em sua Teoria da Constituição ${ }^{49}$ Schmitt encontra forma de retomar tais argumentos, quando busca em Stahl a ideia de que a monarquia constitucional todavia possuía um forte vetor de vontade pessoal, o qual ele operaria

\footnotetext{
${ }^{47}$ Uma livre tradução sugerida para o trecho é: “A essência da monarquia constitucional consiste em que o monarca constitucional todavia tenha um verdadeiro poder [...]”.

${ }^{48}$ Uma livre tradução sugerida para o trecho é: “[...] todavia, sua vontade pessoal significa algo, e não nasce no Parlamento. Segue sendo, pelo asseguramento de suas faculdades, um fator distinto e independente do Poder do Estado”.

${ }^{49}$ Esta obra de Schmitt alcançou grande projeção quando de sua publicação, alcançando prontamente, como recorda Borda (cf. BORDA, 2004, p. 14), a América Latina ainda na década de trinta, imediatamente à data de sua publicação no ano de 1928, mas também a posteriori, quando a realidade espanhola do período pós-Guerra Civil indicava a preparação político-institucional para o regime fascista de direita do generalíssimo Francisco Franco.
} 
como um fator alheio aos poderes do Estado ${ }^{50}$; de fato, verdadeiramente independente de sua estrutura e, mesmo, da vontade popular expressa por meio do Parlamento ${ }^{51}$.

\section{WEIMAR EM CRISE E A TEORIA CONSTITUCIONAL SCHMITTIANA: SOCORRO OU SOCAVAMENTO?}

O nível de rotatividade e tensão política nos anos da República de Weimar não assegurava contra as ameaças apontadas aos rumos do Estado já ao final da década de 1910 e praticamente durante toda a década de 1920. Este foi o contexto histórico não apenas testemunhado por Schmitt, mas aquele que recebeu a sua formação intelectual e no qual terminou por redigir grande parte de seus mais expressivos trabalhos.

Desde o final do Império Guilhermino, portanto, e logo nos primeiros dias da República de Weimar, em 1919, ficara marcado o vácuo simbólico de poder, com a queda da figura do Imperador, mas, desde logo, não o vácuo do poder em sua dimensão fática. O símbolo do poder mediador e, também, aquele que exercera a função de guardião da Constituição, fora defenestrado, o que era provado com o exílio de Guilherme II na Holanda. O retrato político do final da década de 1920 e início da seguinte não seria menos tormentoso, e Schmitt esteve bastante atento, consignando em letras claras no prólogo de seu Der Hüter der Verfassung, quando indicava que a situação constitucional alemã do período poderia ser classificada como de confusão extraordinária (SCHMITT, 2009a, p. 5), tendo sido precisamente a partir da Constituição de Weimar que se dera a intensificação da preocupação com a definição de alguém que protegesse a Constituição; ou seja, que "Seit der Weimarer Verfassung interessiert man sich daher wieder für die besonderen Garantien der Verfassung und fragt nach ihrem Hüter und Wahrer” (SCHMITT, 1996, p. 3), ${ }^{52}$ muito embora o

\footnotetext{
${ }^{50}$ No âmago da filosofia política e jurídica constitucional schmittiana encontramos um forte enfrentamento entre os poderes Executivo e Legislativo, em grande parte derivados da assinalada desconfiança de Schmitt relativamente à estrutura parlamentar - notavelmente, àquela representada pelo parlamento da República de Weimar. Schmitt não encontrará motivos para supor que devesse ser priorizado algum tipo de controle sobre ambos, que devesse ser concebido um terceiro poder a exercer o poder de balanceamento. A atribuição de competência a algum deles para fiscalizar o outro era entendido por Schmitt como uma herança do liberalismo (leia-se, por exemplo, Montesquieu e Guizot), e este, desde logo, era outro de seus inimigos teóricos. Neste contexto, o problema da violação das normas jurídicas que geram problemas de constitucionalidade hão de encontrar resolução no âmbito do Executivo, não do Judiciário nem do Legislativo, cabendo ao primeiro, na figura do Führer, dar-lhe solução definitiva e irrecorrível.

${ }^{51}$ Por definição, tal poder fora concebido para atuar nos moldes de poder mediador, como sugerira Benjamin Constant, embora a prática do poder total viesse a desmentir intervenções tão parcimoniosas e ponderadas, como a teoria parecia sugerir.

${ }^{52}$ Uma livre tradução sugerida para o trecho é: “Desde a Constituição de Weimar voltaram a interessar as garantias especiais da Constituição e se passou a demandar alguém que as protegesse e mantivesse”.
} 
estado de necessidade já existisse em seu ordenamento jurídico e, ainda mais precisamente, a emergência já fosse uma realidade no ordenamento francês do século XIX.

A busca era por um instituto jurídico que constituísse uma figura que, na leitura schmittiana, emergiria como todo-poderosa feito homem, para que interviesse em tempos de anormalidade. A questão imediata que se colocava era, portanto, quem seria este grande ator? Que forma deveria ele tomar? A posição de Kelsen e Schmitt sobre a resposta a esta questão já foi apresentada ao início do trabalho, e neste momento o que desejamos sublinhar é que esta posição antagônica de ambos apenas pode ser sustentada com base na perspectiva teórico-política mantida por ambos, também visceralmente oposta.

Esta oposição em matéria de teoria política pode ser melhor calibrada por meio da leitura da Die Diktatur, publicada em dicionário alguns anos após a sua versão em livro, de 1921. Nesta entrada do dicionário, publicado em 1926, Schmitt expressava sinteticamente a sua compreensão do conceito de ditadura como “[...] die Ausübung einer von rechtl. Schranken befreiten staatl. Gewalt zum Zweck der Überwindung eines abnormen Zustands, insbes. Krieg u. Aufruhr” (SCHMITT, 1995b, p. 33), ${ }^{53}$ referência que já havia realizado em 1921 por meio da ditadura comissária e da ditadura soberana. Este último conceito é concedente de ampla libertação de quaisquer amarras para as ações do soberano, colocando-o em posição de desimpedimento dos obstáculos legais para que, supostamente, empregue esforços endereçados, todos eles, a cumprir os altos fins de superação de agudas crises de época, restando ao seu próprio critério a determinação do que seja compreendido enquanto tal. Ao dar curso a esta opção em uma época em que a simpatia pelo autoritarismo era crescente, restavam descortinadas as vias legais para a instalação do mais puro arbítrio, que logo encontraria as condições ideais para campear livre de instrumentos institucionais criados durante o estado de normalidade. A previsão de reação às situações de emergência não pode equivaler juridicamente a concessão de amplíssimo e ilimitado poder de ação ao poderoso, nem que suponha colocá-lo em posição de libérrima e ilimitada condição de decidir em face do direito posto.

Por meio desta dualidade conceitual criada por Schmitt ao redor do conceito de ditadura, comissária e soberana, ele vinha a reforçar a sua teoria de que as democracias não apenas suportam como também preveem os estados de exceção (SCHMITT, 1995b, p. 35) mas, isto sim, todavia deixava aberto e sem resposta suficiente como o estado de exceção seria superado para que o curso

\footnotetext{
${ }^{53}$ Interessante apontar que este conceito de ditadura que Schmitt escreve para o dicionário de 1926 é compatível apenas com o conceito de ditadura comissária de sua obra de 1921, discrepante do conceito de ditadura soberana. Uma livre tradução sugerida para o trecho é: “[...] é o exercício de um poder estatal livre de barreiras legais com a finalidade de superar um Estado de anormalidade, especialmente de guerra ou sublevação”.
} 
democrático fosse retomado, senão que, inversamente, ele manteve o vetor de suas preocupações sempre apontado para a anormalidade institucional e como dentro dela o poder poderia atuar. Mas se esta é a conceitualização, qual a mais precisa caracterização da ação do ditador e de sua inserção política? Schmitt é também claro: “[...] die Diktatur ist Allmacht ohne Gesetz, rechtlose Macht” (SCHMITT, 2006, p. 126) ${ }^{54}$ e, ainda mais, que "Der Legislator steht außerhalb des Staates, aber im Recht, der Diktator außerhalb des Rechts, aber im Staat. Der Legislator ist nichts als noch nicht konstituiertes Recht, der Diktator nichts als konstituierte Macht” (SCHMITT, 2006, p. 126). ${ }^{55}$

A ideia de normalidade, sem embargo, se encontra logicamente em posição de precedência a de anormalidade, e é precisamente a sua restauração que, ao menos no plano da retórica, é arguida como legitimadora já não apenas da instauração da ditadura como também de todas as medidas que sejam reputadas necessárias pelo ditador ungido a posição de poder para realizar o anunciado movimento restaurador e, portanto, em 1921, para Schmitt a ditadura se resumia a um movimento constitucional-republicano de defesa da liberdade: “[...] ein der republikanischen Verfassung eigentümliches Mittel, die Freiheit zu wahren” (SCHMITT, 2006, p. 6). ${ }^{56}$

Este entreato entre a anormalidade e a restauração da normalidade é marcado pela suspensão ou até mesmo pela eliminação das normas jurídicas, considerando-se que, malgrado Schmitt insistir na posição conceitual do ditador comissário, eis que igualmente é claro quanto à inviabilidade de antecipar todas as medidas que possam ser necessárias ao ditador para que logre o seu cometido. Neste sentido, ainda que implicitamente ou quando angulemos o tema do ponto de vista prático, eis que ficariam autorizadas a aplicação da força, seja ela no plano físico ou jurídico, hipótese em que o ditador, mais além de suspender, viria a romper o ordenamento jurídico vigente.

Neste contexto, Schmitt procurou apresentou a sua argumentação acerca do tema a partir de uma ótica inicialmente preocupada em manter-se fiel à Constituição de Weimar, o que permite a certa linha de comentaristas, entre os quais Bendersky (1989) e Franco de Sá (2012; 2009), manter a interpretação de que Schmitt está entre os seus reais defensores, ainda quando não de seus genuínos apreciadores. Assim, Schmitt apresentou a ideia da irreconciliabilidade da ditadura soberana com o art. 48 e, ainda mais, que haveria incompatibilidade até mesmo com o fundo da Constituição de um Estado de direito (SCHMITT, 2006b, p. 236). O que Schmitt pretendeu, portanto, foi apresentar a

\footnotetext{
${ }^{54}$ Uma livre tradução sugerida para o trecho é: “[...] a ditadura é onipotente sem lei, um poder ajurídico”.

${ }^{55}$ Uma livre tradução sugerida para o trecho é: "O legislador está fora do Estado mas dentro do direito; o ditador está fora do direito, mas dentro do Estado. O legislador não é nada mais que direito ainda não constituído; o ditador não é mais do que poder constituído”.

${ }^{56}$ Uma livre tradução sugerida para o trecho é: “[...] um meio peculiar da Constituição republicana para preservar a liberdade".
} 
ideia de que, do ponto de vista conceitual, apenas a ditadura comissária cabia no art. 48, e este movimento, certamente, permitiu-lhe distanciar-se de críticas dos democratas e republicanos. Sem embargo, como veremos adiante, o conteúdo que Schmitt plantou em sua interpretação do art. 48 e parágrafo $2^{\circ}$ é que seria a chave para dilucidar qual foi a sua real posição em face da Constituição de Weimar, se atuando em seu socorro ou em prol de seu socavamento.

Está implícito no argumento de Schmitt que qualquer tentativa de uma Constituição republicana em realizar a adequação de uma ditadura soberana ao seu texto resultaria em uma completa disponibilização de seu conteúdo republicano-democrático - caso de Weimar - ao arbítrio do ditador soberano. Dotado das competências necessárias, este poderoso soberano estaria sempre disposto a lançar mão de seus poderes extraordinários, orientando-os paraconstitucionalmente (SCHMITT, 2006b, p. 237), conforme os seus interesses e a conveniência política indicada por seu exclusivo julgamento. Disto Schmitt extrai uma conclusão que se revelaria um grave equívoco, político e jurídico; a saber, que “[...] wäre es doch unmöglich, da $\beta$ era uf grund dieser Verfassungsbestimmung [...]. Entweder souveräne Diktatur oder Verfassung: das eine schließt das andere aus” (SCHMITT, 2006b, p. 237), ${ }^{57}$ erro histórico quando, em perspectiva, observamos o desenrolar da história alemã nas décadas de 1930 e 1940. Portanto, é com boa dose de razão que Albanese questiona e implicitamente responde: "Ma un presidente che emana leggi come rappresentante del potere costituente del popolo esercita qualcosa che somiglia molto, ormai, a una ditadura sovrana [...]” (ALBANESE, 1996, p. 46). De fato, o exercício de um poder deste naipe é qualquer coisa demasiado similar a uma ditadura soberana, ainda que Schmitt insista em sua apresentação como ditadura comissária, ao que parece, com o intuito de manter as aparências de constitucionalidade da posição que sustentava.

Mas se em tempos de exceção é constituído um personagem tão forte quanto o ditador, então, quem representa o personagem efetivamente exercerá a guarda da Constituição; se o soberano é aquele que decide sobre o Estado de exceção, quem, pois, guardará a Constituição precisamente nestes momentos de mais aguda crise, senão o próprio ditador soberano schmittiano? Resta, todavia, a questão sobre o que, realmente, este guardião se colocaria em posição de defender, se a Verfassung (Constituição) ou a Verfassungsgesetz (lei constitucional). O que está aqui em causa com este último questionamento, portanto, é a possível limitação da competência do guardião, pois acaso a sua competência fosse apenas a de proceder à defesa da lei constitucional

\footnotetext{
${ }^{57}$ Uma livre tradução sugerida para o trecho é: “[...] seria impossível que ele exercesse uma ditadura soberana com base nesta cláusula constitucional [...]. Ou ditadura soberana ou Constituição: uma coisa exclui a outra”.
} 
(Verfassungsgesetz), então, ficaria clara a limitação à atuação no sentido de proteger a lei de violações.

Sem embargo, quando Schmitt propõe o título de seu livro como Hüter der Verfassung, descortina sub-repticiamente um horizonte conceitual incerto e politicamente perigoso. O que está em questão é que quando ao ditador soberano e pretenso guardião da Constituição for outorgada competência para mais além da mera proteção da lei constitucional (Verfassungsgesetz), então, serão abertas as portas para que invada o próprio conceito de Constituição. A gravidade disso reside em que, na gramática de Schmitt, a Constituição implica a ação do próprio corpo político titular do poder constituinte - a saber, o povo, de cuja ação homogênea advém o conteúdo da Constituição. Portanto, guardar a Constituição equivaleria a fazer-se titular desse poder, e é sobre esse poder constituinte originário, então, que todo aquele a quem seja atribuída a "guarda da Constituição”, conceitualmente, estaria em posição de decidir e, por via de consequência, sobrepondo-se àquela decisão política primária ${ }^{58}$ e, portanto, ao superior poder homogêneo que era a chave da democracia schmittiana do ponto de vista conceitual. ${ }^{59}$

Do ponto de vista de sua concepção conceitual e inserção institucional, para Schmitt sempre esteve claro que o soberano guardião não protegeria a Constituição sob as vestes judiciais. Para Schmitt é um erro supor que o fato de exercer o controle do direito material colocaria o Poder Judiciário em condições de receber a competência para atuar como guardião da Constituição, uma vez que tal tarefa protetora residiria mais além do que na mera determinação de que certos conteúdos de leis ordinárias são ou não são constitucionais e, por conseguinte, que devam ou não ser cumpridos enquanto normas (SCHMITT, 1996, p. 12). ${ }^{60}$ Para Schmitt, o soberano que guarda

\footnotetext{
${ }^{58}$ Este é conceito cuja posição é ocupada em Kelsen pela norma fundamental enquanto origem do ordenamento jurídico, cuja fonte última da cadeia de validade encontra residência e pretensa morada segura na Grundnorm.

${ }^{59}$ É possível ainda analisar a posição do guarda da Constituição, em Schmitt, por meio da retomada do conceito, pelo autor, de democracia enquanto homogeneidade. Neste caso, a concessão da guarda da Constituição ao Hüter der Verfassung constituiria uma violação da democracia, e não o seu asseguramento, conquanto promotora da intervenção de alguém alheio sobre a Verfassung (Constituição) democraticamente (homogeneamente) elaborada. Embora Schmitt seja claro em que o poder constituinte não seja estático e nem fique a sua vontade cristalizada em algum momento da história e, logo, indisponível para o próprio sujeito político, contudo, não seria este sujeito histórico o próprio Hüter der Verfassungsgesetz (guardião da lei constitucional), mas apenas um guardião constituído, e não alguém a quem a massa homogênea tenha delegado o poder constituinte - aliás, indelegável por antonomásia. Não sendo assim, teria de ser admitido, portanto, que o Hüter der Verfassung disporia da plenitudo potestatis que, originária e diretamente, Schmitt reconhece apenas ao soberano ditador, figura cuja existência ele distancia do texto em sua interpretação da Constituição de Weimar.

${ }^{60}$ Ao referir-se aos tribunais, dizia Schmitt que "Der Irrtum, sie als solche zu bezeichnen, liegt allerdings nahe, wenn sie ein sogenanntes materielles richterliches Prüfungsrecht ausüben, d. h. einfache Gesetze auf ihre inhaltliche Übereinstimmung mit verfassungsgesetzlichen Bestimmungen prüfen und im Kollisionsfall dem einfachen Gesetz die Anwendung versagen” (SCHMITT, 1996, p. 12).
} 
todos os tempos e circunstâncias, e a Constituição inclusive, habita e se deixa conhecer em um momento, e Schmitt o explicita: "Souverän ist, wer über den Ausnahmezustand entscheidet" (SCHMITT, 2009b, p. 13). ${ }^{61}$

\section{CONSIDERAÇÕES FINAIS}

O debate entre Schmitt e Kelsen propõe a retomada de uma série de questões sobre uma disputa de fundo que tem adquirido maior atualidade nas democracias em processo de consolidação; qual seja, a discussão sobre o papel do Poder Judiciário e, em especial, no que tange ao controle de constitucionalidade. A disputa entre a órbita política e a esfera jurídica tem apresentado progressiva radicalização, e as vias de resolução têm sido obstruídas por um debate que recorre a razões obscuras e de motivações turvas. Parcialmente, a crise das democracias contemporâneas encontra reflexo nas incertezas, menos sobre o papel do guardião da Constituição - alvo histórico da disputa entre Schmitt e Kelsen, já razoavelmente estabilizada - do que sobre qual seja o approach necessário; vale dizer, sobre como realizar o equilíbrio entre as razões jurídicas e as razões políticas e sua argumentação jurídica.

O cenário de embates entre as forças políticas, tanto dentro do parlamento como fora dele, e as pressões que grupos organizados procuram exercer sobre o Poder Judiciário, podem apontar tanto para uma situação de (indesejado) equilíbrio como, por outro lado, a depender da estrutura histórica de instituições dadas, em caso de debilidade destas, apontar para um débâcle. O que está em questão e é o fiel da balança, portanto, é a capacidade de resistência destas instituições às pressões externas de atores dotados de alto poder para exercê-las mas, não menos, da própria sociedade civil em compreender os processos históricos e de reagir a eles.

O cenário típico das crises institucionais é propício para a afirmação de poderes singulares e de figuras que se apresentam em territórios místicos, personagens nebulosamente travestidos como salvadores de males sem-fim. É perfil que não discrepa em essência de seu desenho pela teoria política schmittiana, convictamente antidemocrática e antiparlamentar e, logicamente, avessa ao pluralismo característico da teoria política kelseniana. Nos dias que correm, como antanho, à crise econômica se soma uma crise política e, também como outrora, grupos filofascistas, quer à direita ou à esquerda, engrossam a vida pública e encontram nas vias populistas e demagógicas o espaço para cultivar seu perigoso caldo ideológico. Daquele contexto de crise democrática

\footnotetext{
${ }^{61}$ Uma livre tradução sugerida para o trecho é: “Soberano é aquele que decide sobre o Estado de exceção”.
} 
vivenciada por Schmitt e Kelsen sugerimos poder extrair referências úteis para analisar os presentes desequilíbrios, se não pela definição da competência específica do protetor da Constituição, isto sim, por uma melhor circunscrição acerca do ponto de equilíbrio técnico entre o elemento jurídico e o político de que devem estar eivadas as decisões deste protetor.

Neste particular, a retomada da leitura do embate entre Schmitt e Kelsen explicita a opção por uma estrutura jurídico-política em que o poder político é desvelado em suas desmesuradas possibilidades de interferir na esfera legal e nas instituições sem maior possibilidade de controles formais ou materiais por parte do poder político democrático popular. Sem embargo, o movimento jurídico formalista de corte kelseniano, voltado a cristalizar o político a partir da esfera legal, finalmente dá espaço e vez a uma opção que restringe o traçado de novos cenários e termina, paradoxalmente, por impedir o desenvolvimento do princípio democrático da titularidade do poder pelo povo. Este cenário afeta de forma direta a concepção de democracia manejada pelos Estados ocidentais, na medida em que são realizados movimentos de solapamento do poder político que conceitualmente são afeitos à titularidade popular e, por outro lado, não menos impacta o fato de que o direito pretenda cristalizar formas de vida, ideologias e experiências institucionais, indisponibilizando-as ao titular político popular. Via inversa, o perigo já foi identificado em algum momento por Zagrebelsky, ao sublinhar o alto risco para as democracias de que a voz do povo seja tomada sem sentido radical, frente à qual devessem se dobrar as autoridades, as instituições e, em suma, o próprio Estado de Direito (ZAGREBELSKY, 2012, p. 147).

Um dos aspectos de fundo deste debate entre Schmitt e Kelsen, e que o torno atual, portanto, são as duas concepções de estruturação da política, do direito e, em suma, do Estado. Desde o ângulo proposto neste texto, o que recomenda o retorno à análise da matriz conceitual desenvolvida na polarização realizada por estes dois autores é a busca de um ponto de equilíbrio entre o exercício do poder político de forma dinâmica e, por outro lado, o seu controle com viés de petrificação. Este ponto intermédio seria representado por preceitos democraticamente construídos ao longo do tempo e que serviriam como ponto de estabilidade para o desenvolvimento das instituições e de amparo para os dias mais difíceis. Sob uma perspectiva de abandono desta busca, então, seria possível perscrutar um horizonte em que as soluções autoritárias ou ditatoriais proliferem; ou seja, que sob as vestes democráticas de realização da democracia política a expensas de vetustas instituições e formalidades, que sob o pretexto das melhores e mais bem intencionadas mentes operantes por meio de razões mítico-teológicas, seja, tarde demais, desvelada a sua essencial desvinculação e desapreço tanto à democracia quanto às liberdades. 


\section{REFERÊNCIAS}

ALBANESE, Luciano. Schmitt. Roma/Bari: Editori Laterza, 1996. 168 p.

BAÑO LEÓN, José María. Estudio Preliminar. In: SCHMITT, Carl. Ensayos sobre la dictadura. Madrid: Tecnos, 2013. p. XV-LXXVI. 397 p.

BENDERSKY, Joseph William. Carl Schmitt: teorico del Reich. Bologna: Il Mulino, 1989. 369 p.

BÍBLIA SAGRADA MÉDIA. São Paulo: Editora Ave Maria, 2007. 180 p.

BUENO, Roberto. Carl Schmitt hoje: política, direito e teologia. São Paulo: Max Limonad, 2015. $708 \mathrm{p}$.

DONOSO CORTÉS, Juan. Textos Políticos. Madrid: Ediciones Rialp, 1954. 487 p.

DYZENHAUS, David. Legality and Legitimacy. Carl Schmitt, Hans Kelsen and Hermann Heller in Weimar. Oxford: Oxford University Press, 2003. 283 p.

FRANCO DE SÁ, Alexandre. Metamorfose do poder. Prolegómenos schmittianos a toda a sociedade futura. Rio de Janeiro: Via Verita, 2012. 164 p.

. O poder pelo poder. Ficção e ordem no combate de Carl Schmitt em torno do poder. Braga: Centro de Filosofia da Universidade de Lisboa, 2009.

GASIÓ, Guillermo. Introducción. In: KELSEN, Hans. ¿Quién debe ser el defensor de la Constitución? Madrid: Tecnos, 1995. p. IX-XLIV.

HATTENHAUER, Hans. Los fundamentos historico-ideologicos del derecho alemán. Entre la jerarquía y la democracia. Madrid: Editorial de Derecho Reunidas, 1981. 409 p.

HERRERA, Carlos Miguel. La polémica Schmitt-Kelsen sobre el guardián de la Constitución. Revista de Estudios Políticos (Nueva Época). Núm. 86, Octubre-Diciembre. 1994, p. 195-227.

JELLINEK, Georg. Teoría General del Estado. México: Fondo de Cultura Económica, 2000. 687 p.

JELLINEK, Walter. El proceso de elaboración de la Constitución de Weimar. In: LA CONSTITUCIÓN DE WEIMAR (Texto de la Constitución alemana de 11 de agosto de 1919). p. 77114. Madrid: Tecnos, 2010. 358 p.

KELSEN, Hans. ¿Quién debe ser el defensor de la Constitución? Madrid: Tecnos, 1995. 82 p.

¿Quién debe ser el defensor de la Constitución? In: KELSEN, Hans; SCHMITT, Carl. La polémica Schmitt / Kelsen sobre la justicia constitucional: El defensor de la Constitución versus ¿Quién debe ser el defensor de la Constitución? Madrid: Tecnos, 2009a. 366 p.

. De la esencia y el valor de la democracia. Oviedo: KRK Ediciones, 2009b.

. Jurisdição constitucional. São Paulo: WMF Martins Fontes, 2003a. 320 p.

Revista da Faculdade de Direito - UFPR, Curitiba, vol. 60, n. 3, set./dez. 2015, p. 103-136 
KENNEDY, Ellen. Carl Schmitt en la República de Weimar. La quiebra de una Constitución. Madrid: Tecnos, 2012. 283 p.

LA CONSTITUCIÓN DE WEIMAR (Texto de la Constitución alemana de 11 de agosto de 1919). Madrid: Tecnos, 2010. 358 p.

LOMBARDI, Giorgio. Estudio preliminar. In: SCHMITT, Carl; KELSEN, Hans. Carl Schmitt y Hans Kelsen. La polémica Schmitt / Kelsen sobre la justicia constitucional: El defensor de la Constitución versus ¿Quién debe ser el defensor de la Constitución? Madrid: Tecnos, 2009. p. IXLXXII.

LONGO, Gianfranco. Il concetto di mutamento costituzionale in Hans Kelsen e Carl Schmitt. Rivista Internazionale di Filosofia del Diritto. IV Serie, LXXIII, Aprile- Giugno, 1996, p. 256-262.

SCHMITT, Carl. Der Hüter der Verfassung. Berlin: Duncker \& Humblot, 1996. 159 p. 2010a. 95 p.

Diálogo sobre el poder y el acceso al poderoso. México: Fondo de Cultura Económica, . Dictadura. In: SCHMITT, C. Ensayos sobre la dictadura. Madrid: Tecnos, 2013c. Pp. 351359. $397 \mathrm{p}$.

- Die Diktatur des Reichspräsident nach Artikel 48 der Weimarer Verfassung. In: SCHMITT, C. Die Diktatur. Berlin: Duncker \& Humblot, 2006b. Pp. 211-257. 257 p.

. Die Diktatur. Berlin: Duncker \& Humblot, 2006a. 257 p.

Die geistesgeschichtliche Lage des heutigen Parlamentarismus. Berlin: Duncker \& Humblot, 2010b. 90 p.

. Diktatur. In: MASCHKE, Gunter. (Org.). Staat, Grossraum, Nomos. Berlin: Duncker \& Humblot, 1995. Pp. 33-37. 668 p.

. El defensor de la Constitución. In: SCHMITT, C.; KELSEN, Hans. La polémica Schmitt / Kelsen sobre la justicia constitucional: El defensor de la Constitución versus ¿Quién debe ser el defensor de la Constitución? Madrid: Tecnos, 2009a. Pp. IX-LXXII.

El significado en el Derecho Público del reglamento de necesidad, especialmente en su validez jurídica. In: SCHMITT, C. Ensayos sobre la dictadura. Madrid: Tecnos, 2013d. Pp. 361397. 397 p.

. Ensayos sobre la dictadura. Madrid: Tecnos, 2013a. 397 p.

. Gesetz und Urteil: Eine Untersuchung zum Problem der Rechtspraxis. Berlin: Beck C. H., 2009c. 129 p.

Hugo Preuss e la dottrina tedesca dello Stato. In: SCHMITT, Carl. Democrazia e liberalismo. Referendum e iniziativa popolare. Hugo Preuss e la dottrina tedesca dello Stato. Milano: Giuffrè, 2001a. Pp. 87-123. 123 p. 
. La defensa de la Constitución. Madrid: Tecnos, 1998. 251 p.

. La dictadura del Presidente del Reich según el art. 48 de la Constitución de Weimar. In:

SCHMITT, C. Ensayos sobre la dictadura. Madrid: Tecnos, 2013b. Pp. 295-350. 397 p.

. La dictadura. Madrid: Alianza, 2009d. 338 p.

. Politische Theologie. Berlin: Duncker \& Humblot, 2009b. 70 p.

. Referendum e iniziativa popolare. In: SCHMITT, Carl. Democrazia e liberalismo. Referendum e iniziativa popolare. Hugo Preuss e la dottrina tedesca dello Stato. Milano: Giuffrè, 2001b. Pp. 27-87. 123 p.

. Teoría de la Constitución. Madrid: Alianza, 1992. 377 p.

. Verfassungslehre. Berlin: Duncker \& Humblot, 2003. 404 p.

SCHWAB, Georg. The Challenge of the Exception. An Introduction to the Political Ideas of Carl Schmitt between 1921 and 1936. New York: Greenwood Press, 1989. 174 p.

VIANELLO, Lorenzo Córdova. Derecho y poder. México: Fondo de Cultura Económica, 2010. 320 p.

ZAGREBELSKY, Gustavo. A crucificação da democracia. São Paulo: Saraiva, 2012. 155 p.

\title{
CARL SCHMITT X HANS KELSEN: DEFENDER OR SEIGNIOR OF THE CONSTITUTION?
}

\begin{abstract}
The political crises of the contemporary democracies find their explanation in the past arguments composed by detractors of the parliamentarian democratic theory and practice. The debate between Schmitt and Kelsen on the protector of the Constitution and the (il)limitation, which must characterize the exercise of its power, contains one of the juridical and political reasons that exceeds its own time. We suggest that reason still beats and fulfills one of the many grooves of the contemporary democracy's crisis, i.e., the unfinished debate on the supremacy of law over politics or politics over law, or still, the supremacy of the technique over the world of life (Lebenswelt) or, instead, the world of life over any type of regulation turned to assure the liberties. Starting from that premise this article looks to recognize - aside the self-perception of each author about his theories who really support a theory composed by a defender, and who by a seignior of the Constitution.
\end{abstract}

KEYWORDS: Carl Schmitt. Hans Kelsen. Judicial Review. Weimar Republic. Dictatorship. 